\title{
Glutamate Transporter mRNA Expression in Proliferative Zones of the Developing and Adult Murine CNS
}

\author{
Margaret L. Sutherland, ${ }^{1,2}$ Tracy A. Delaney, ${ }^{2}$ and Jeffrey L. Noebels ${ }^{1,2}$ \\ ${ }^{1}$ Division of Neuroscience, ${ }^{2}$ Developmental Neurogenetics Laboratory, Department of Neurology, Baylor College of \\ Medicine, Houston, Texas 77030
}

Neuronal migration, differentiation, and synapse formation are developmental processes within the CNS significantly influenced by ionotropic and metabotropic glutamate receptor activity. Extracellular glutamate concentrations mediating this activity are regulated by transport proteins localized in neuronal and glial cell membranes. We have used in situ hybridization analysis with subtype-specific antisense-oligonucleotides to study the distribution of glia-specific excitatory amino acid transporter (mEAAT1 and mEAAT2) mRNAs during the later stages of embryogenesis and postnatal CNS development. Distinct but overlapping embryonic and postnatal patterns of localization were observed for the two transporter transcripts. Both mEAAT1 and mEAAT2 mRNAs were found during the peak period of gliogenesis (E15-E19) in the telencephalic and mesencephalic CNS proliferative zones. The overall expression of mEAAT1 mRNA diminished after the completion of cell migration, whereas mEAAT2 mRNA expression increased significantly during postnatal development. Interestingly, mEAAT2 transcript expression continued in the subventricular zone postnatally and persisted in this proliferative zone in the adult brain. From PO onward, mEAAT1 mRNA was present predominantly in the cerebellar Purkinje cell layer and at a much lower abundance in the cortex, hippocampus, basal nuclei, and septum, whereas from P7 onward, mEAAT2 mRNA expression increased throughout most of the neuraxis. Postnatally, transcripts for mEAAT1 and mEAAT2 were found in cell bodies, processes, and commissural white matter tracts of the CNS. The divergent temporal and spatial expression of EAAT subtypes and their persistence in mature fiber tracts and radial glia layers reveal that specific EAATs are likely to play multiple distinct roles in the developing and adult CNS, including the regulation of cell proliferation, axon-glia interactions, and neuronal survival.

Key words: excitatory amino acid transporters; development; in situ hybridization; proliferative zones; CNS; temporal and spatial expression
Glutamate, the principle excitatory amino acid neurotransmitter of the mammalian CNS, is a signal for a number of diverse developmental events, including cell migration and differentiation (Pearce et al., 1987; Mattson et al., 1988; Komuro and Rakic, 1993), activation of second-messenger cascades involved in the modulation of neuronal and astrocytic proliferation (Nicoletti et al., 1990; LoTurco and Kriegstein, 1991), regulation of early gene expression (Arenander et al., 1989), cell death (Oka et al., 1993), and participation in the construction, refinement, and maintenance of synaptic circuitry (Mattson ct al., 1988; McDonald and Johnston, 1990). The extracellular level of glutamate, as well as fast transmission at some glutamatergic synapses (Mennerick and Zorumski, 1994; Takahashi ct al., 1995), is regulated by diffusion and active reuptake of neurotransmitter into presynaptic terminals and surrounding glial cells by membrane-localized transport proteins (for review, see Amara and Arriza, 1993).

Uptake is an electrogenic process that moves glutamate and $\mathrm{Na}^{+}$ions into the cell, while countertransporting $\mathrm{K}^{+}$and $\mathrm{OH}-$ or $\mathrm{HCO}_{3}$ ions outward (Bouvier et al., 1992; Attwell and Mobbs, 1994). The quantity of charge translocated with glutamate is voltage- and subtype-dependent (Wadiche et al., 1995a,b). In the adult brain, an essential role of excitatory amino acid transport is

Received Nov. 28, 1995; revised Jan. 18, 1996; accepted Jan. 23, 1996.

This work was supported by National Institutes of Health Grants NS29709 and NS11535. M.L.S. is the recipicnt of an Amcrican Epilepsy Socicty Postdoctoral Fellowship. We thank Alex Kogan for photographic assistance.

Correspondence should be addressed to Dr. Margaret Sutherland, Department of Neurology, Baylor College of Medicine, One Baylor Plaza, Houston, TX 77030.

Copyright 1996 Socicty for Neuroscience $0270-6474 / 96 / 162191-17 \$ 05.00 / 0$ the maintenance of extracellular levels of glutamate below neurotoxic concentrations (Nicholls and Attwell, 1990; Kanai et al., 1993). Alteration of ion gradients can cause a reversal of excitatory amino acid transporter (EAAT) function (Attwell et al., 1993), resulting in elevated extracellular glutamate levels and excitotoxic cell death (Choi et al., 1987; Ikeda et al., 1989; Szatkowski et al., 1990; Bouvier et al., 1992; Madl and Burgesser, 1993).

A gene family that mediates the cellular uptake of acidic and neutral amino acids in vertebrates has been identificd by CDNA isolation (for reviews, see Kanai et al., 1993; Kanner, 1993; Amara and Arriza, 1993). Four distinct subtypes of EAATs (Kanai and Hediger, 1992; Pines et al., 1992; Storck et al., 1992; Shashidharan and Plaitakis, 1993; Tanaka, 1993a,b; Arriza et al., 1994; Kawakami et al., 1994; Kirschner et al., 1994; Shashidharan et al., 1994; Fairman et al., 1995; Sutherland et al., 1995) have been defined by differences in sequence, pharmacology, tissue distribution, and channcl-like properties. EAAT1, EAAT2, and EAAT3 share a $>50 \%$ amino acid identity among subtypes and a $>90 \%$ amino acid identity across species. Recent immunocytochemical analysis of EAAT subtypes has identified EAAT1 and EAAT2 (Rothstein et al., 1994; Lehre et al., 1995) proteins in the cell bodies and processes of astroglia and the EAAT3 protein in neuronal cell bodies, axons, presynaptic terminals, and dendrites (Rothstein et al., 1994).

The existence of multiple EAAT subtypes raises the possibility that EAATs may play a variety of roles in the developing and adult CNS. These predicted roles depend in part on the temporal 


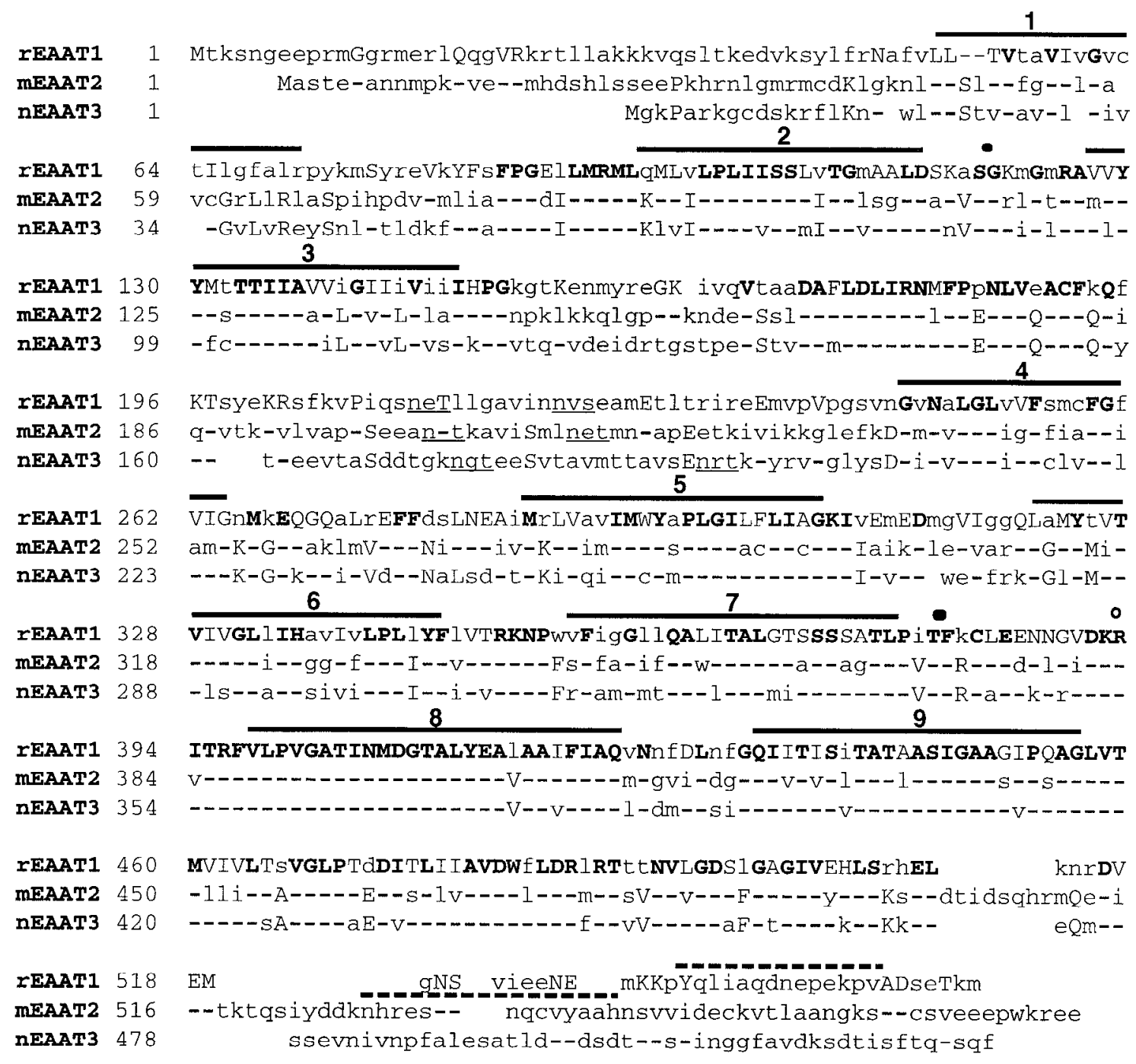

Figure 1. Amino acid alignment of EAAT (1-3) subtypes. Identity between sequences is shown by a dash. Amino acids common to all three transporter proteins are indicated by bold lettering in the rEAAT1 sequence. Putative transmembrane domains, as determined by Kyte and Doolittle (1982) hydrophobicity analysis, are indicated by solid lines and numbers (1-9) above the aligned sequences. Consensus sites for PKC (S/T-X-R/K) and PKA $(\mathrm{R} / \mathrm{K}-\mathrm{X}-\mathrm{X}-\mathrm{S} / \mathrm{T})$ phosphorylation, which are common to all sequences, are shown above the alignment. Putative sites for $\mathrm{N}$-linked glycosylation (N-X-S/T) are underlined. The amino acid positions of probes used for in situ histochemistry are indicated by dashed lines above the sequences, rEAAT1, (rat); mEAAT2, (mouse); nEAAT3, (rabbit). Amino acid identity (41-50\%) is observed among EAAT subtypes.

onset and cellular localization of EAAT subtype mRNA expression. Therefore we have used in situ hybridization analysis to determine the distribution of the two glial-type mouse glutamate transporter transcripts mEAAT1 and mEAAT2 during embryonic and postnatal murine CNS development.

\section{MATERIALS AND METHODS}

RNA preparation and cDNA synthesis. Total RNA was isolated from adult mouse $C 57 \mathrm{BL} / 6 \mathrm{~J}$ tissues using the acidified guanidine thiocyanate technique of Chomczynski and Sacchi (1987). First-strand cDNAs synthesized with avian myeloblastosis virus reverse transcriptase (RT) (Amersham, Arlington Heights, IL) from the total RNAs were used as templates in PCR reactions containing $50 \mathrm{~mm}$ Tris, $\mathrm{pH} 8.0,50 \mathrm{mM} \mathrm{NaCl}, 200 \mu \mathrm{M}$ dNTPs (Pharmacia, Piscataway NJ), 2.5 units of Taq DNA polymerase (Promega, Madison WI), and $10 \mathrm{pmol}$ of each primer. PCR reactions were incubated at $55^{\circ} \mathrm{C}$ for $5 \mathrm{~min}$ and then amplificd at $95^{\circ} \mathrm{C}$ for $1 \mathrm{~min}$, $55+0.50^{\circ} \mathrm{C} / \mathrm{cycle}$ for $2 \mathrm{~min}$, and $72^{\circ} \mathrm{C}$ for $3 \mathrm{~min}$ for 30 cycles. The final extension was at $72^{\circ} \mathrm{C}$ for $10 \mathrm{~min}$. Primers were designed to the $5^{\prime}-$ and $3^{\prime}$-untranslated regions of the rEAAT1 and rEAAT2 sequences. RT-PCR products were separated on $0.7 \%$ agarose gels, immobilized onto Hybond-N membranes (Amersham), and hybridized at $60^{\circ} \mathrm{C}$ with a ${ }^{32} \mathrm{P}$ - nicked translated transcript-specific probe. Washes were performed at $65^{\circ} \mathrm{C}$ in $0.1 \times \mathrm{SSC}\left(0.015 \mathrm{M} \mathrm{NaCl}, 0.0015 \mathrm{M} \mathrm{Na}_{3}\right.$ citrate, pH 7.6).

Section preparation. Embryos and postnatal brains were obtained by timed matings, with the appcarance of a vaginal plug designated as embryonic day 0.5 (E0.5) and the day of birth as P0. Embryos were removed from anesthetized mice by cesarean section. For postnatal analysis, mice were killed by spinal dislocation, and the brains were rapidly removed, frozen on dry ice, wrapped in parafilm (Fisher, Pittsburgh, PA), and stored at $-70^{\circ} \mathrm{C}$ until use. Horizontal serial sections (12 $\mu \mathrm{m})$ were cut with a cryostat and thaw-mounted onto poly-L-lysine-coated (Sigma, St. Louis, MO) slides. Sections were dried for $30 \mathrm{~min}$ at room temperature before being fixed for $5 \mathrm{~min}$ in $4 \%(\mathrm{w} / \mathrm{v})$ paraformaldehyde (Fisher) in $1 \times$ PBS $(130 \mathrm{~mm}$ sodium chloride, $7 \mathrm{~mm}$ disodium hydrogen orthophosphate, and $3 \mathrm{~mm}$ sodium dihydrogen orthophosphate). After washing in $1 \times \mathrm{PBS}$, scctions were dehydrated in an ascending EtOII series.

Oligonucleotide probes. Antisense oligonucleotides were designed to mouse $(\mathrm{m})$ EAAT1 and EAAT2 sequences that correspond to nonhomologous regions of the rEAAT1 and mEAAT2 amino acid alignments, as illustrated in Figure 1. mEAAT1 and mEAAT2 antisense oligonucleotides were $3^{\prime}$ end-labeled using terminal deoxynucleotidyl transferase (Promega, Madison WI) and $\left[\alpha-{ }^{35} \mathrm{~S}\right] \mathrm{dATP}(1300 \mathrm{Ci} / \mathrm{mmol})$ (DupontNEN, 


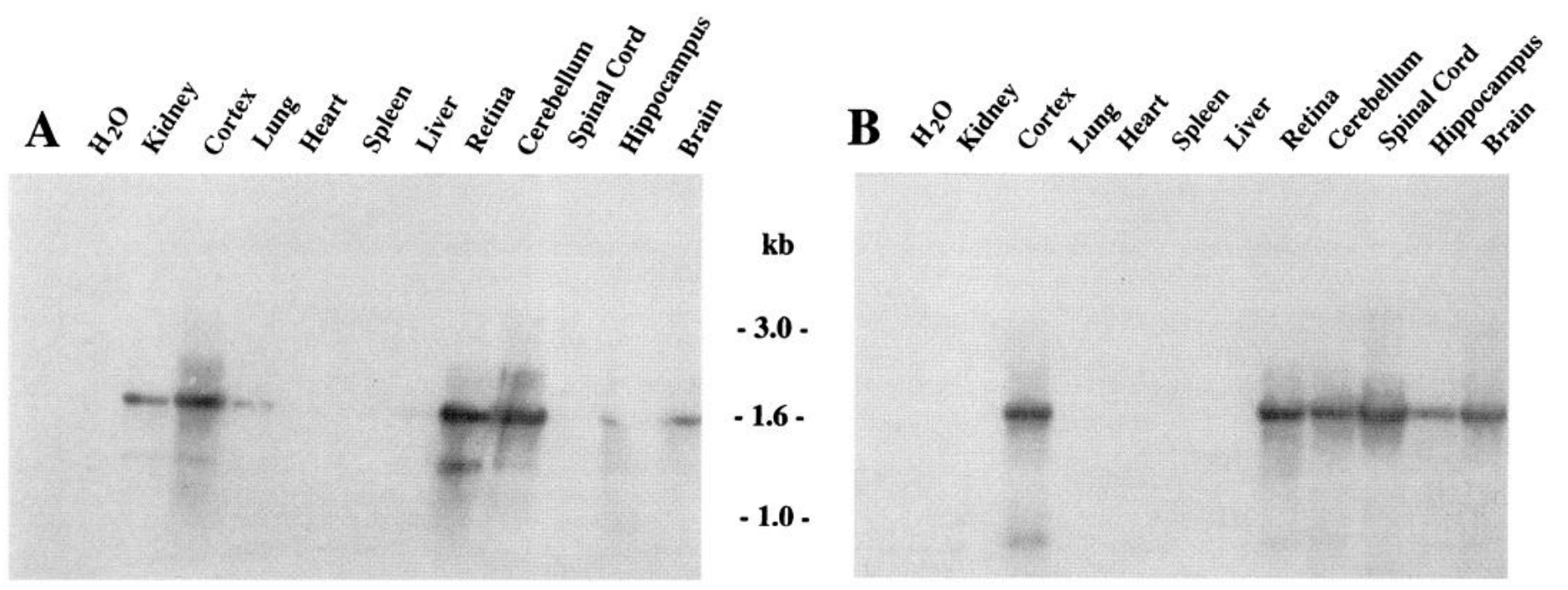

Figure 2. Adult tissue distribution of the transcripts for murine EAATs, mEAAT1 and mEAAT2. First-strand cDNA was reverse-transcribed with RAV2 by random-priming total RNA isolated from various murine adult tissues (see Materials and Methods). Before the transporter mRNA expression experiment, primers specific to the $5^{\prime}$ - and $3^{\prime}$-terminal coding regions of the murine $\beta$ actin gene were used in PCR reactions to determine the quality of the first-strand synthesis (data not shown), and equivalent concentrations of first-strand cDNAs were then used in subsequent PCR reactions. Southern blots were hybridized overnight at $60^{\circ} \mathrm{C}$ with ${ }^{32} \mathrm{P}$-labeled cDNA probes for $(A)$ mEAAT1 and $(B)$ mEAAT2 and washed at high stringency before autoradiography. The predominant reaction products of $\sim 1.6 \mathrm{~kb}$ (EAAT1) and $1.7 \mathrm{~kb}$ (EAAT2) are of the expected size for the PCR primers used. Templates used in the PCR experiments are indicated above the lanes. As shown in $B$, mEAAT2 mRNA expression is CNS-specific.

Boston, MA) to a specific activity of $\sim 10^{9} \mathrm{dpm} / \mu \mathrm{g}$. Unincorporated radiolabeled nucleotides were removed on Quickspin G25 columns (Boehringer Mannheim, Indianapolis, IN).

$m R N A$ localization. All hybridizations were standardized to contain 2.0 $\times 10^{2} \mathrm{dpm} / \mu \mathrm{l}$ of a glutamate transporter-specific ${ }^{35} \mathrm{~S}$-labeled oligonucleotide probe in hybridization buffer containing $50 \%(\mathrm{v} / \mathrm{v})$ formamide, $4 \times$ $\mathrm{SSC}, 25 \mathrm{~mm}$ sodium phosphate, $\mathrm{pH} 7.0,1 \mathrm{~mm}$ sodium pyrophosphate, 20 $\mathrm{mm}$ dithiothreitol, $5 \times$ Denhardt's solution, $10 \%(\mathrm{w} / \mathrm{v})$ dextran sulfate, $200 \mu \mathrm{g} / \mathrm{ml}$ acid-alkali hydrolyzed salmon sperm DNA (Boehringer Mannheim), $100 \mu \mathrm{g} / \mathrm{ml}$ polyadenylic acid, and $120 \mu \mathrm{g} / \mathrm{ml}$ heparin. Sections were hybridized overnight at $42^{\circ} \mathrm{C}$. Control sections were hybridized in the presence of a 50 -fold (postnatal) or 100-fold (embryonic) excess of the appropriate unlabeled oligonucleotide. After hybridization, coverslips were removed in $1 \times \mathrm{SSC}$ at room temperature, and the sections were washed in $0.3 \times \mathrm{SSC}$ for $30 \mathrm{~min}$ at $55^{\circ} \mathrm{C}$. Slides were rinsed once at room temperature in $0.3 \times \mathrm{SSC}$, dehydrated sequentially in an ascending ethanol series, and air-dried. All wash solutions contained $10 \mathrm{~mm}$ dithiothreitol. Sections were exposed to Kodak X-Omat film at room temperature for $20 \mathrm{~d}$ before the slides were dipped in Kodak NBT-2 emulsion. After exposure for $50 \mathrm{~d}$ at $4^{\circ} \mathrm{C}$, slides were processed in Kodak D19 developer for $2 \mathrm{~min}$ at $17^{\circ} \mathrm{C}$, briefly rinsed in distilled water, fixed in $30 \%$ (w/v) sodium thiosulfate for $4 \mathrm{~min}$, and finally washed in distilled water for $10 \mathrm{~min}$. Sections were dried overnight at room temperature before being counterstained with $0.05 \%(\mathrm{w} / \mathrm{v})$ thionin, differentiated in an ascending ethanol series, cleared in Histo-clear (National Diagnostics, Atlanta, GA) and mounted in DPX (BDH, Poole, England). Autoradiographic images generated on $\mathrm{x}$-ray film were printed onto Kodak Kodabrome II RC photographic paper, giving reverse images. All emulsiontreated sections were photographed onto Kodak Tech-Pan film using a Leitz microscope and a $35 \mathrm{~mm}$ camera with dark-field optics. Scale bars were determined using a precalibrated graticule.

\section{RESULTS}

\section{Tissue distribution of mEAAT1 and mEAAT2 mRNAs}

To study mEAAT1 and mEAAT2 transcript distribution, total RNA from several adult tissues was isolated and used in RT-PCR reactions with EAAT subtype-specific primers. Southern hybridization analysis of the RT-PCR electrophoresed products shown in Figure 2 indicates that detectable levels of the mEAAT1 transcript were expressed in the adult CNS (cerebellum, spinal cord, hippocampus, retina, and cortex) as well as non-neuronal tissues (lung, liver, and kidney). The presence of the mEAAT1 transcript in non-neuronal tissues such as the kidney suggests that this subtype of glutamate transporter plays a regulatory role in glutamate homeostasis, as has been suggested for the EAAT3 subtype, which is found in the epithelial cells of the small intestine and kidney (Kanai and Hediger, 1992). The EAAT3 gene maps to a locus associated with dicarboxylic aminoaciduria, a disorder characterized by increased urinary excretion of glutamate and aspartate and accompanied by developmental neurological abnormalities (Swarna et al., 1989).

In contrast to the broad tissue distribution of mEAAT1 mRNA, the mEAAT2 transcript was exclusively expressed in the adult CNS (neocortex, retina, hippocampus, spinal cord and cerebellum) (Fig. 2). Placement of this transporter gene in the central region of mouse chromosome 2 near quantitative trait loci that modulate neuroexcitability and seizure frequency in mouse models of alcohol withdrawal and epilepsy (Kirshner et al., 1994) suggests a possible role for the EAAT2 gene in neurological disorders associated with excitotoxic cell death.

\section{Embryonic expression of mEAAT1 and mEAAT2 transcripts in CNS}

Using subtype-specific oligonucleotide probes, we examined the regional and cellular mRNA distribution of EAAT1 and EAAT2 genes in a series of whole-mount sagittal sections from 15 (E15), 17 (E17), and 19 (E19) day mouse embryos. Control hybridization experiments using a 100-fold excess of unlabeled probe resulted in autoradiograms virtually devoid of signal, except for some nonspecific labeling of surface ectoderm in several E15 sagittal sections (data not shown). The results compiled from Figures 3-5 and data not shown are summarized in Table 1. Emulsion-dipped slides were used to determine the cellular localization of mEAAT transcripts.

Glutamate transporter mRNAs were expressed in distinct spa- 

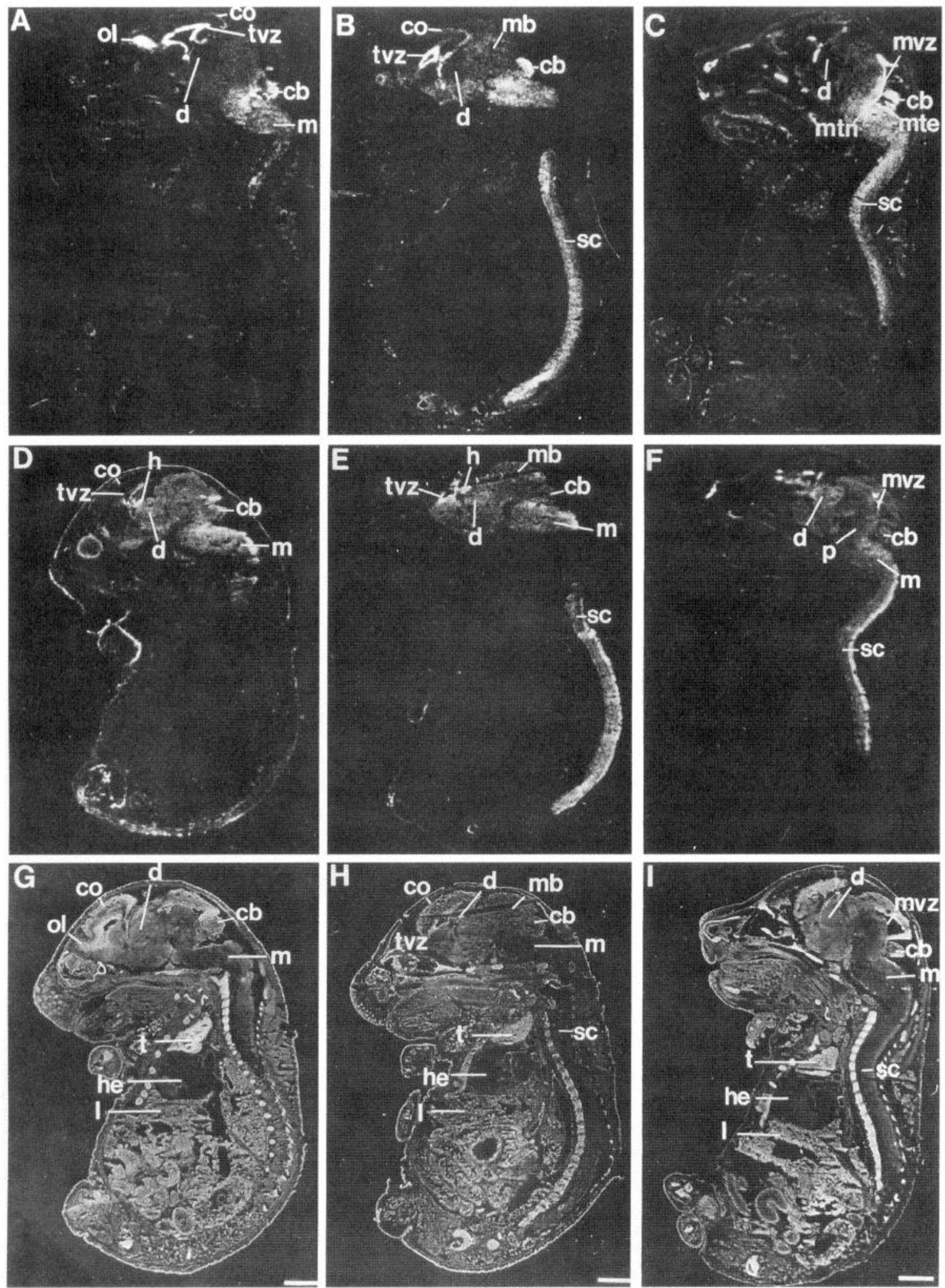

Figure 3. Late embryonic tissue distribution of mEAAT1 and mEAAT2 mRNAs. $A-F, \mathrm{X}$-ray autoradiograms illustrating the distribution of mEAAT1 $(A-C)$ and mEAAT2 $(D-F)$ mRNAs in sagittal sections of E15 $(A, D), \mathrm{E} 17(B, E)$, and E19 $(C, F) \mathrm{C} 57 \mathrm{BL} / 6$ mouse embryos. $G-I$, Nissl stains of E15 $(G)$, E17 $(H)$, and E19 $(I)$ whole-mount embryo sections. Both mEAAT1 and mEAAT2 mRNAs were present in the telencephalic and mesencephalic proliferative zones of the embryonic CNS. co, Neopallial cortex; $c b$, cerebellar primordium; $d$, diencephalon; $h$, hippocampus; $h e$, heart; $l$, liver; $m$, medulla oblongata; $m b$, midbrain; $m t e$, medullary tegmental neuroepithelium; $m t n$, motor trigeminal nucleus; $m v z$, mesencephalic ventricular zone; ol, olfactory lobe; $p$, pons; $s c$, spinal cord; $t v z$, telencephalic ventricular zone; $t$, thymus. Scale bars: $G, 1.4 \mathrm{~mm} ; H, 1.5 \mathrm{~mm} ; I, 1.6 \mathrm{~mm}$. 

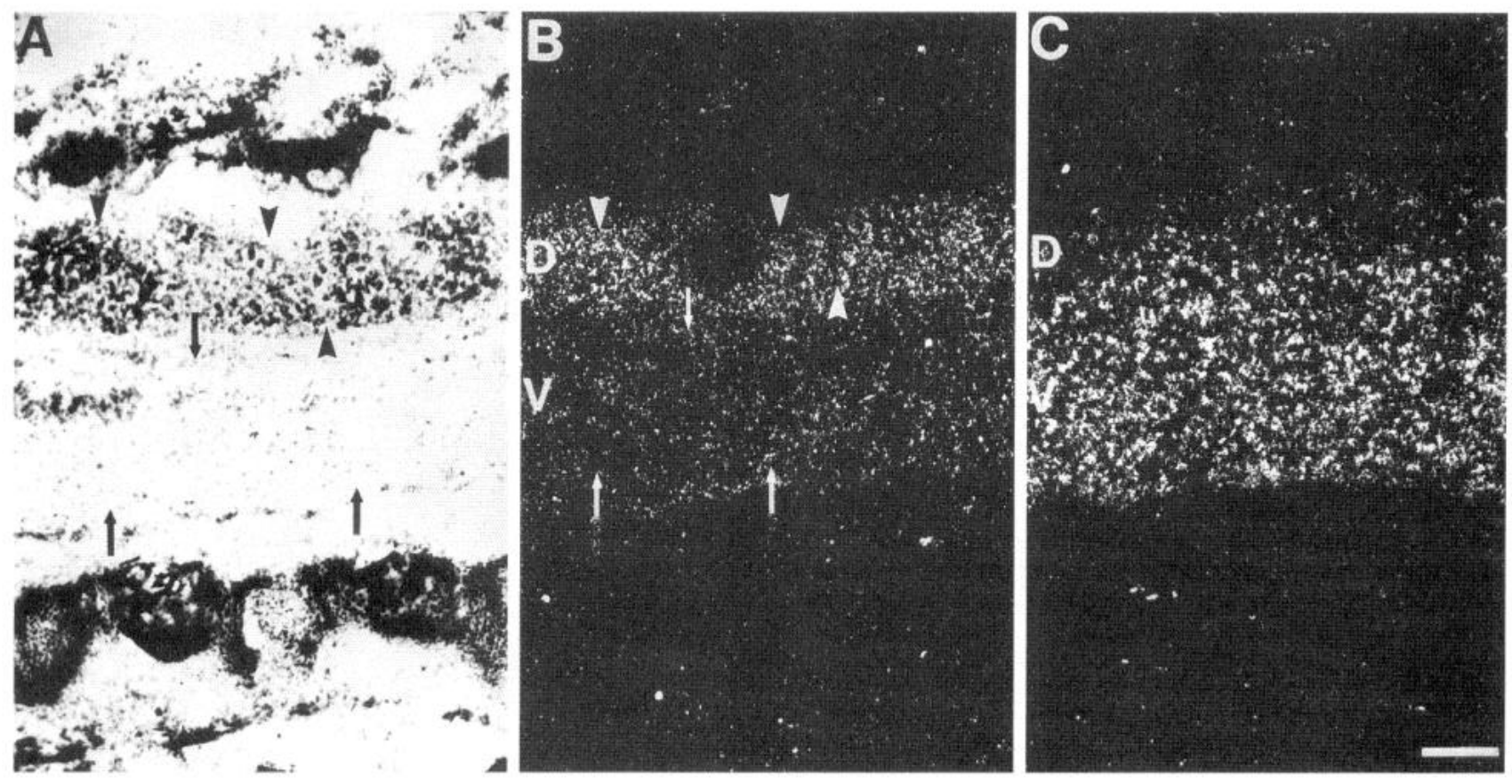

Figure 4. Differential embryonic expression of mEAAT1 and mEAAT2 mRNAs in the spinal cord. Distributions of mEAAT1 and mEAAT2 mRNAs in an emulsion-dipped sagittal section of E19 spinal cord. Bright-field $(A)$ and dark-field $(B)$ illumination of mEAAT1 mRNA and dark-field $(C)$ illumination of mEAAT2 mRNA in the midcervical region of spinal cord. Arrowheads $(A, B)$ indicate abundant silver grain distribution corresponding to mEAAT1 mRNA over the dorsal $(D)$ gray region, and arrows $(A, B)$ indicate sparse silver grain distribution for the mEAAT1 transcript over the ventral $(V)$ gray region of spinal cord. The mEAAT2 transcript shows a predominantly ventral distribution. Scale bar (shown in $C$ ): $18 \mu$ m.

tial patterns in the E15, E17, and E19 day spinal cord, where the mEAAT1 and mEAAT2 transcripts were most abundant in the dorsal and ventral horn cells, respectively (Figs. 3, 4). This dorsal/ ventral spatial pattern of mEAAT mRNA expression was also present in the medulla oblongata in the later stages of embryogenesis. At E15, E17, and E19, mEAAT1 mRNA was expressed abundantly in the cerebellar primordium and in the telencephalic and mesencephalic ventricular zones (Figs. 3, 5; Table 1). The mEAAT1 mRNA was also weakly expressed in the embryonic neopallial cortex, midbrain, and hypothalamus. The signal intensity of the mEAAT2 probe was less abundant than the signal intensity of the mEAAT1 probe in the ventricular areas of the olfactory lobe and cerebellar primordium (Fig. 5). mEAAT2 mRNA was not detected in the neopallial cortex during embryonic development (Fig. 5). Of the two EAAT mRNAs, only the transcript for mEAAT2 was found in the thalamus and colliculi (Fig. 3). The mEAAT2 mRNA was expressed abundantly in the hippocampus (Fig. 5) during the later stages of embryogenesis.

\section{Postnatal CNS expression of mEAAT1 and mEAAT2 mRNAs}

Horizontal sections of $\mathrm{P} 0, \mathrm{P} 7, \mathrm{P} 14$, and adult mouse brains were probed with glutamate transporter transcript-specific antisense oligonucleotides to determine the regional and cellular localization of mEAAT1 and mEAAT2 mRNAs during postnatal development. Control hybridization experiments using a 50-fold excess of unlabeled probe resulted in autoradiograms devoid of signal (data not shown). The results from Figures 6-12 and data not shown are compiled in Table 2.

\section{Cortex}

Spatiotemporal patterns of mEAAT1 and mEAAT2 mRNA expression changed considerably during postnatal cerebral cortical development. In the P0 cerebral cortex, the highest signal inten- sities for both transporter mRNAs were associated with the lateral ventricular and subventricular proliferative zones of the CNS. These sites of cell proliferation are associated with fate determination of immature neuroblasts and gliogenesis during early postnatal CNS development (Privat and Leblond, 1972). Migrating neuronal and glial cells originating from the ventricular and subventricular zones are guided into the appropriate layers by radial glial processes (Rakic, 1971, 1972). The completion of cerebral cortex stratification occurs around P6 in the mouse (Miller, 1988) and is coincidental with the first detection of mEAAT2 mRNA in all layers of the neocortex, including the subventricular zone (Fig. 6). The temporal expression of both glutamate transporter subtypes in the cortex appears to peak at P14 (Fig. 6).

Emulsion-dipped slides of $\mathrm{P} 0$ and $\mathrm{P} 14$ cerebral cortex revealed that for the mEAAT1 transcript, silver grains were clustered primarily over cell somas, whereas a more diffuse pattern of grains was present over cell processes. The highest levels of mEAAT1 mRNA expression in the P14 cerebral cortex were found in layers II, III, and IV (Fig. 7). In P14 cortical layers I-V, the mEAAT2 probe localized over some cell somas, but in contrast to the mEAAT1 probe, the mEAAT2 probe predominantly labeled cell processes, with the highest signal intensities in layers III, IV, and $\mathrm{V}$ (Fig. 7). In the adult cortex, changes in the silver grain distribution for the mEAAT2 transcript were observed in the subventricular zone and cortical layer VI, where grains were distributed predominantly over cell somas (Fig. 8).

\section{Hippocampus}

Although the adult spatial patterns of mEAAT1 and mEAAT2 mRNA expression in the hippocampal formation were present at birth, the signal intensities for the two probes in various hippocampal regions changed considerably during postnatal devel- 

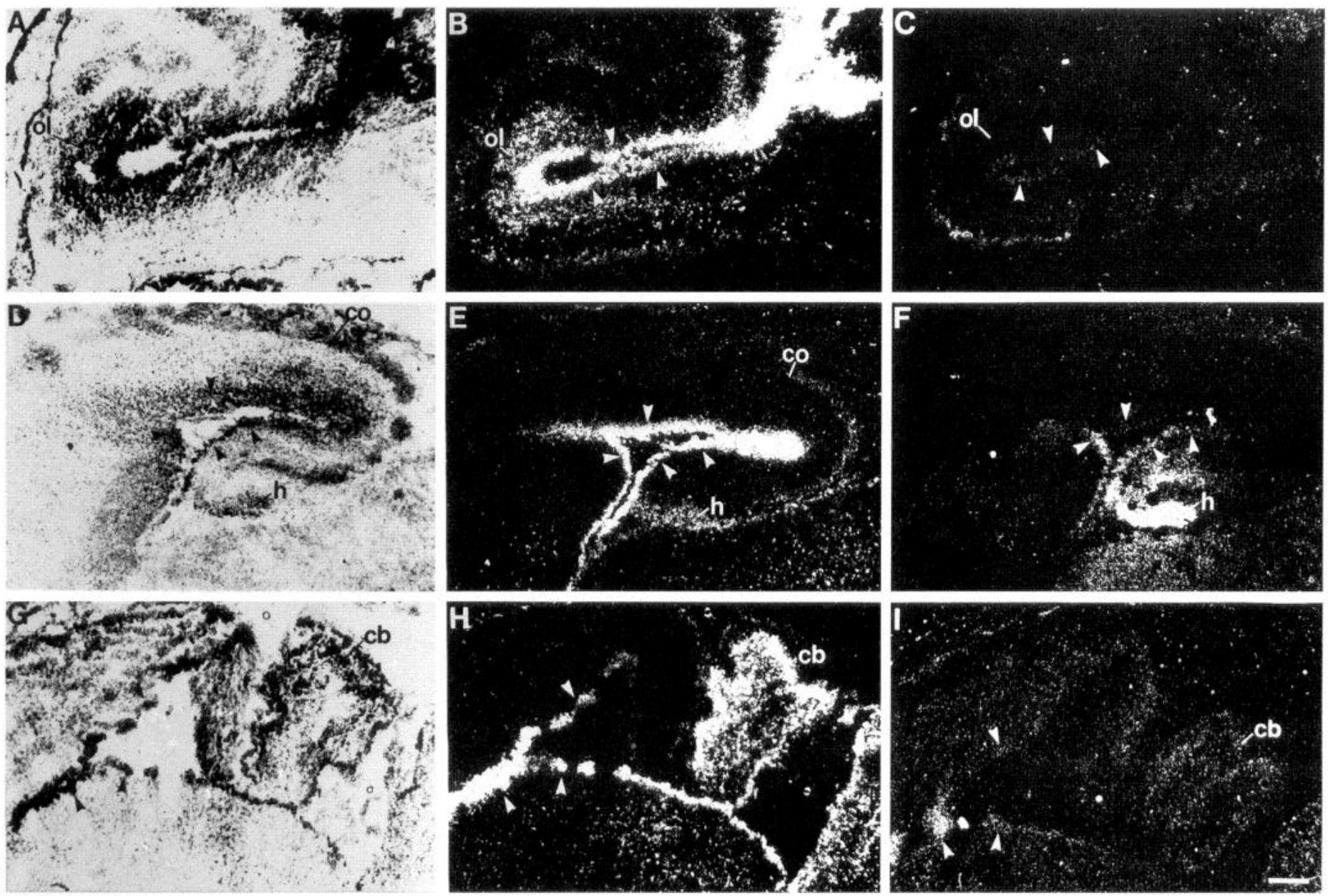

Figure 5. Expression of mEAAT1 and mEAAT2 mRNAs in the CNS during embryogenesis. Distributions of mEAAT1 and mEAAT2 mRNAs in the olfactory lobe, forebrain, and cerebellar primordium of E19 C57BL/6 mouse embryo. $A-C$, Bright-field $(A)$ and dark-field $(B)$ views of mEAAT1 mRNA and a dark-field view of mEAAT2 $(C)$ mRNA in the olfactory lobe (arrowheads indicate olfactory ventricular zone). $D-F$, Bright-field $(D)$ and dark-field $(E)$ view of mEAAT1 mRNA and dark-field views of mEAAT2 $(F)$ mRNA in the cortical and hippocampal regions of E19 mouse embryo (arrowheads indicate telencephalic ventricular zone). $G-I$, Bright-field $(G)$ and dark-field $(H)$ views of mEAAT1 mRNA and a dark-field view of mEAAT2 $(I)$ mRNA in the cerebellar primordium region (arrowheads indicate mesencephalic ventricular zone). $c o$, Cortical plate; $c b$, cerebellar primordium; $h$, hippocampus; $o l$, olfactory lobe. Scale bar (shown in $I$ ): $22 \mu \mathrm{m}$.

Table 1. Embryonic distribution of mEAAT1 and mEAAT2 mRNAs in the CNS

\begin{tabular}{|c|c|c|c|c|c|c|}
\hline \multirow[b]{2}{*}{ Region } & \multicolumn{2}{|l|}{ E15 } & \multicolumn{2}{|l|}{ E17 } & \multicolumn{2}{|l|}{ E19 } \\
\hline & mEAAT1 & mEAAT2 & mEAAT1 & mEAAT2 & mEAAT1 & mEAAT2 \\
\hline Neopallial cortex & + & - & + & - & + & - \\
\hline Intermediate zone & + & - & + & - & + & - \\
\hline Ventricular zone & ++++ & + & ++++ & ++ & ++++ & ++ \\
\hline Olfactory lobe & ++++ & + & ++ & + & ++ & + \\
\hline Midbrain & - & ++ & - & ++ & + & ++ \\
\hline Hypothalamus & + & ++ & + & ++ & + & ++ \\
\hline Thalamus & - & ++ & - & ++ & - & ++ \\
\hline Hippocampus & ++ & +++ & ++ & +++ & ++ & +++ \\
\hline Spinal cord & ++ & ++ & +++ & ++ & +++ & +++ \\
\hline Cerebellar primordium & ++++ & + & ++++ & + & ++++ & + \\
\hline Colliculi & - & ++ & ++ & ++ & - & ++ \\
\hline Septum & - & + & + & ++ & + & + \\
\hline Pons & +++ & ++ & +++ & ++ & +++ & ++ \\
\hline Medulla oblongata & ++ & ++ & ++ & ++ & ++ & ++ \\
\hline Mesencephalic ventricular zone & + & - & +++ & + & +++ & + \\
\hline
\end{tabular}




\begin{tabular}{|c|c|c|c|c|c|c|c|c|}
\hline \multirow[b]{2}{*}{ Region } & \multicolumn{2}{|l|}{1 Day } & \multicolumn{2}{|l|}{7 Day } & \multicolumn{2}{|l|}{14 Day } & \multirow{2}{*}{$\frac{\text { Adult }}{\text { mEEAT1 }}$} & \multirow[b]{2}{*}{ mEEAT2 } \\
\hline & mEEAT1 & mEEAT2 & mEEAT1 & mEEAT2 & mEEAT1 & mEEAT2 & & \\
\hline \multicolumn{9}{|l|}{ Cortex } \\
\hline Layer II & ++ & + & + & +++ & + & +++ & + & +++ \\
\hline Layer III-IV & ++ & + & + & ++++ & + & ++++ & + & +++ \\
\hline Layer IV-VI & + & + & + & ++ & + & +++ & + & ++ \\
\hline Lateral ventricular zone/subependymal zone & +++ & ++ & - & ++ & - & +++ & - & ++ \\
\hline Entorhinal cortex & + & + & + & +++ & + & ++++ & + & ++++ \\
\hline \multicolumn{9}{|l|}{ Hippocampus } \\
\hline CA1 & - & + & + & ++ & - & ++ & - & ++ \\
\hline $\mathrm{CA} 2$ & - & + & + & +++ & - & +++ & - & +++ \\
\hline $\mathrm{CA} 3$ & - & ++ & + & +++ & - & +++ & - & +++ \\
\hline Dentate gyrus & + & ++ & + & ++ & + & ++ & + & ++ \\
\hline Hilus & ++ & ++ & + & +++ & + & +++ & + & +++ \\
\hline Stratum moleculare & ++ & - & + & ++ & ++ & +++ & + & +++ \\
\hline Stratum lacunosum & + & + & + & ++ & + & +++ & + & ++ \\
\hline Stratum radiatum & + & + & + & + & + & ++ & + & ++ \\
\hline Stratum oriens & + & + & + & + & + & ++ & + & ++ \\
\hline \multicolumn{9}{|l|}{ Basal nuclei } \\
\hline Caudate putamen & - & - & + & ++ & + & ++ & + & ++ \\
\hline Accumbens & - & - & + & ++ & + & ++ & + & ++ \\
\hline Globus pallidus & - & - & + & ++ & + & ++ & + & ++ \\
\hline \multicolumn{9}{|l|}{ Septum } \\
\hline Lateral & + & + & + & + & + & ++ & + & ++ \\
\hline Medial & + & - & + & + & + & ++ & + & ++ \\
\hline Triangular & + & - & + & ++ & + & ++ & + & ++ \\
\hline \multicolumn{9}{|l|}{ Thalamus } \\
\hline Anterodorsal thalamic nucleus & - & - & + & + & ++ & +++ & + & ++ \\
\hline Medial habenular nucleus & + & + & + & ++ & + & +++ & - & ++ \\
\hline Ventrolateral geniculate nucleus & - & - & - & ++ & - & ++ & - & ++ \\
\hline Dorsal lateral geniculate nucleus & - & - & - & + & - & ++ & - & ++ \\
\hline Laterodorsal thalamic nucleus & - & + & - & + & + & ++ & + & ++ \\
\hline Reticular thalamic nucleus & - & - & - & ++ & - & ++ & - & ++ \\
\hline Ventral posteromedial thalamic nucleus & - & - & - & ++ & + & ++ & + & ++ \\
\hline Lateral posterior thalamic nucleus & - & - & - & + & - & ++ & - & ++ \\
\hline \multicolumn{9}{|l|}{ Colliculi } \\
\hline Inferior & - & + & - & ++ & - & +++ & - & +++ \\
\hline Superior & - & + & - & ++ & - & ++ & - & ++ \\
\hline \multicolumn{9}{|l|}{ Subiculum } \\
\hline Presubiculum & + & + & + & ++ & + & +++ & + & +++ \\
\hline Parasubiculum & + & + & + & ++ & + & +++ & + & +++ \\
\hline \multicolumn{9}{|l|}{ Cerebellum } \\
\hline Purkinje cell layer & $+t+$ & + & ++++ & +++ & ++++ & +++ & ++++ & +++ \\
\hline Molecular layer & - & - & + & + & + & + & + & + \\
\hline Internal granular cell layer & + & + & + & + & + & + & + & + \\
\hline External granular cell layer & - & - & - & - & - & - & - & - \\
\hline \multicolumn{9}{|l|}{ White matter tracts } \\
\hline Corpus callosum & + & ++ & - & + & - & + & - & + \\
\hline Fimbria & ++ & ++ & - & + & + & + & + & + \\
\hline
\end{tabular}

The specific activity of each probe was identical $\left(0.2 \times 10^{3} \mathrm{cpm} / \mu \mathrm{l}\right)$, allowing direct comparison of probe intensities. The signal intensities are assessed as intense $++++;$ strong +++ ; moderatc + ; wcakly positive 1 ; or not detcctable.

opment. Transcripts for both mEAAT1 and mEAAT2 were present in the granule cells of the P0 dentate gyrus, in cells of the hilus, and in the stratum oriens, stratum radiatum, and stratum lacunosum moleculare (Figs. 6, 9). The mEAAT2, but not the mEAAT1 transcript was present throughout the $P 0$ pyramidal cell layer. Emulsion-dipped $\mathrm{PO}$ sections revealed that the silver grain distribution for mEAAT1 was predominantly over cell bodies, whereas the signal for the mEAAT2 transcript was distributed more diffusely, suggesting localization within cell processes (Fig. 9).

Neurogenesis in most of the hippocampal formation is completed before birth in the fetal mouse and rat (Bayer, 1980). The exception to this developmental pattern occurs in the dentate gyrus, where neurons continue to form until P20. Postnatal cell 

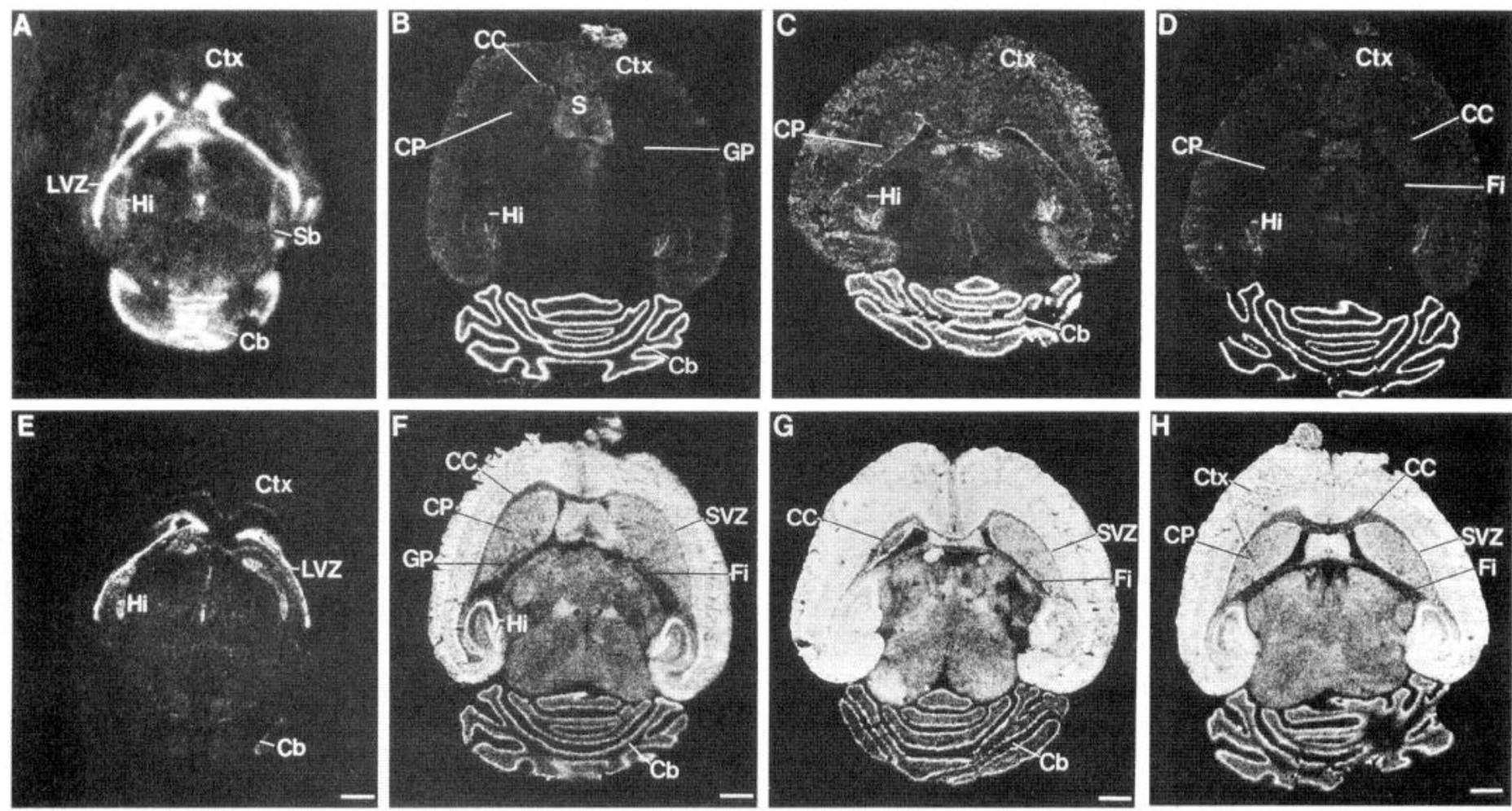

Figure 6. CNS postnatal expression of mEAAT1 and mEAAT2 mRNAs. $A-H$, X-ray autoradiographs illustrating the distribution of mEAAT1 $(A-D)$ and mEAAT2 $(E-H)$ mRNAs in horizontal sections of $\mathrm{P} 0(A, E), \mathrm{P} 7(B, F), \mathrm{P} 14(C, G)$, and adult $(D, H) \mathrm{C} 57 \mathrm{BL} / 6$ mouse brains. The mEAAT1 probe shows weak but diffuse forebrain expression with an apparent peak in the level of expression at P14, whereas the mEAAT2 probe shows strong and persistent forebrain expression. In contrast to mEAAT2 mRNA expression, the signal intensity of the mEAAT1 probe is significantly stronger in the cerebellar cortex. $\mathrm{Cb}$, Cerebellum; $C C$, corpus callosum; $C P$, caudate putamen; $C t x$, cortex; $F i$, fimbria; $G P$, globus pallidus; $H i$, hippocampus; $L V Z$, lateral ventricular zone; $S$, septum; $S b$, subiculum; $S V Z$, subventricular zone. Scale bars: $E, 0.71 \mathrm{~mm} ; F, 0.9 \mathrm{~mm} ; G, 0.9 \mathrm{~mm} ; H, 1.0 \mathrm{~mm}$.

proliferation in the dentate gyrus is most pronounced in the hilus and at the base of the granular cell layer (Altman and Das, 1966), two areas in which the mEAAT1 and mEAAT2 mRNAs were expressed abundantly in the P7 hippocampus (Figs. 9, 10). The mEAAT1 transcript was expressed moderately in the stratum radiatum, stratum oriens, and stratum lacunosum moleculare and was weakly present in the dentate granule cell layer. Expression of mEAAT2 mRNA was abundant in the CA3 pyramidal cell layer, hilus, and stratum lacunosum moleculare, and faintly detectable in the stratum oriens. At the cellular level, the signals for both transcripts were associated with the cell somas and processes (Fig. 9).

In the adult hippocampus, the transcript for mEAAT2 was expressed abundantly in the pyramidal cell layer, with the ranking of signal intensity being CA $3>C A 2 \gg C A 1$ (Fig. 6). Signals for both transcripts were abundant in a band of hilar cells that border the inner dentate granule cell layer (Fig. 10) and in the stratum oriens and lacunosum moleculare (Fig. 10). Only weak signals for both transcripts were found in the dentate granule cell layer (Fig. 10).

\section{Basal ganglia}

Expression of the mEAAT2 transcript was first detected in the globus pallidus, caudate putamen, and accumbens nuclei at P7 (Fig. 6). In contrast, at P7, mEAAT1 mRNA was not detectable in the globus pallidus (Fig. 6). This pattern of expression for mEAAT1 and mEAAT2 mRNAs in the basal ganglia was maintained throughout postnatal development (Table 2).

\section{Diencephalon}

Regional changes in thalamic expression of the two mEAAT transcripts occurred during the first postnatal week. mEAAT2 mRNA was weakly and diffusely expressed throughout the thalamus and hypothalamus at $\mathrm{P} 0$, whereas only the transcript for mEAAT1 was present in the medial habenular nucleus (Fig. 6, Table 2). By P7, the mEAAT2 transcript was found in the ventral and dorsal lateral genicular nucleus, ventral posteromedial and reticular thalamic nuclei, medial and lateral habenular nucleus, lateral dorsal and posterior nucleus, and anterodorsal thalamic nucleus. This pattern of thalamic expression was maintained throughout postnatal development (Table 2). Expression of the mEAAT1 transcript remained restricted to the medial habenular nucleus in the P7 thalamus and was not detectable in the anterodorsal, ventral posteromedial, and lateral dorsal thalamic nuclei until P14. The P14 pattern of thalamic expression for the mEAAT1 transcript was maintained in the adult thalamus (Fig. 6, Table 2).

\section{Cerebellum}

During postnatal cerebellar development, the transcripts for mEAAT1 and mEAAT2 were expressed predominantly in the Purkinje cell layer (Fig. 11, Table 2). Cellular localization of the mEAAT1 transcript in both the P0 and adult cerebellum revealed that silver grains were clustered over some but not all Purkinje cell bodies and over most cell somas and proximal processes of Bergmann glia (Fig. 11). The distribution of mEAAT2 mRNA in the P0 cerebellum was limited to a faint signal in the granular and Purkinje cell layers (data not shown). In the adult cerebellum, 

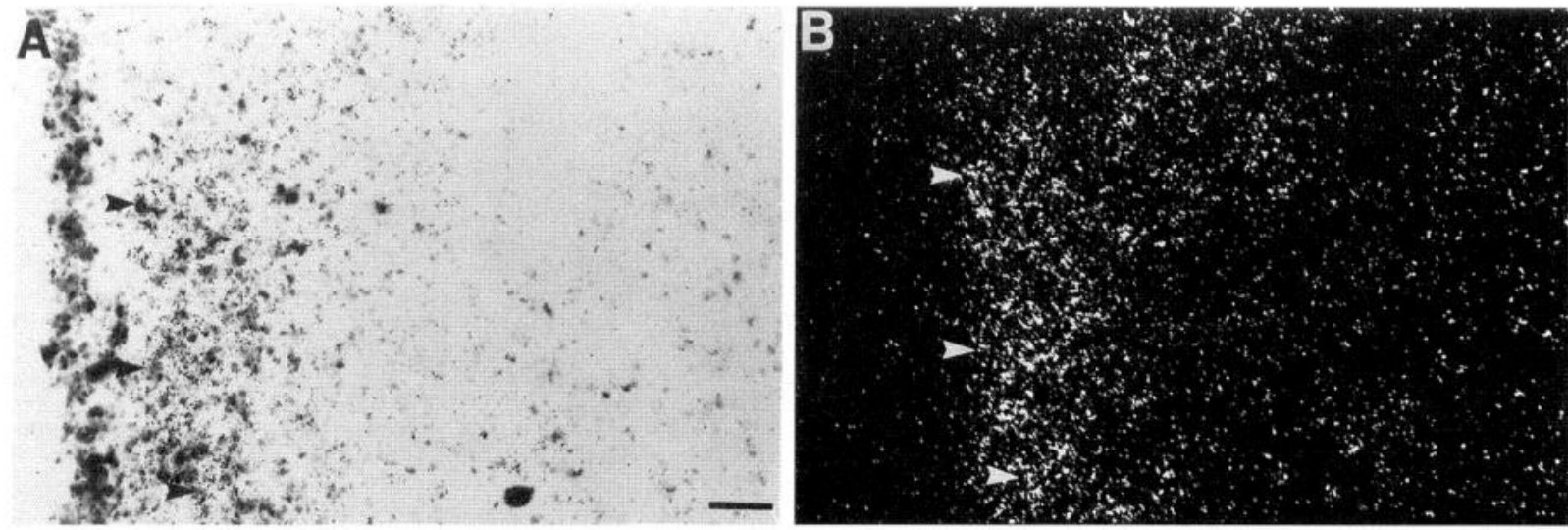

C
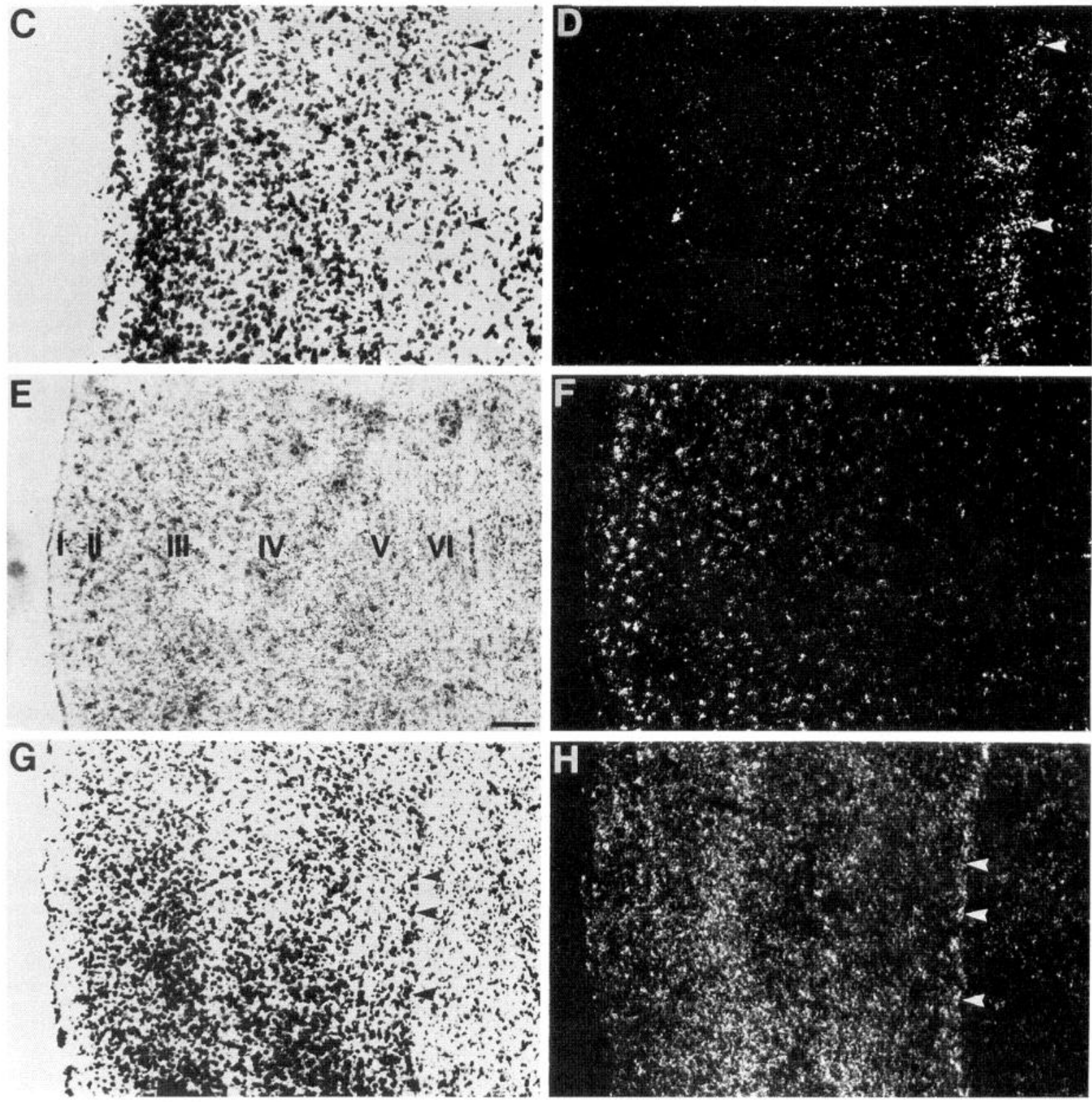

Figure 7. Postnatal cortical distributions of mEAAT1 and mEAAT2 transcripts. Distributions of mEAAT1 and mEAAT2 mRNAs in the cortex of P0 $(A-D)$ and P14 $(E-H)$ C57BL/6 mouse brains. Bright-field $(A)$ and dark-field $(B)$ views of mEAAT1 mRNA distribution in the developing P0 cerebral cortex. Arrowheads indicate superficial cell layer. Bright-field $(C)$ and dark- field $(D)$ views of mEAAT2 mRNA distribution in the P0 cerebral cortex. Arrowheads indicate the position of cells in the subventricular zone. Bright-field $(E)$ and dark-field $(F)$ views of mEAAT1 mRNA in the P14 cerebral cortex, showing the predominant labeling of cell somas in cortical layers II and III. Bright-field $(G)$ and dark-field $(H)$ views of mEAAT2 mRNA distribution in the P14 cerebral cortex; arrowheads indicate cells labeled in the subventricular zone. P14 cortical layer designations are indicated by roman numerals in $E$. Scale bars: $A, 8.4 \mu \mathrm{m} ; E, 10 \mu \mathrm{m}$. 

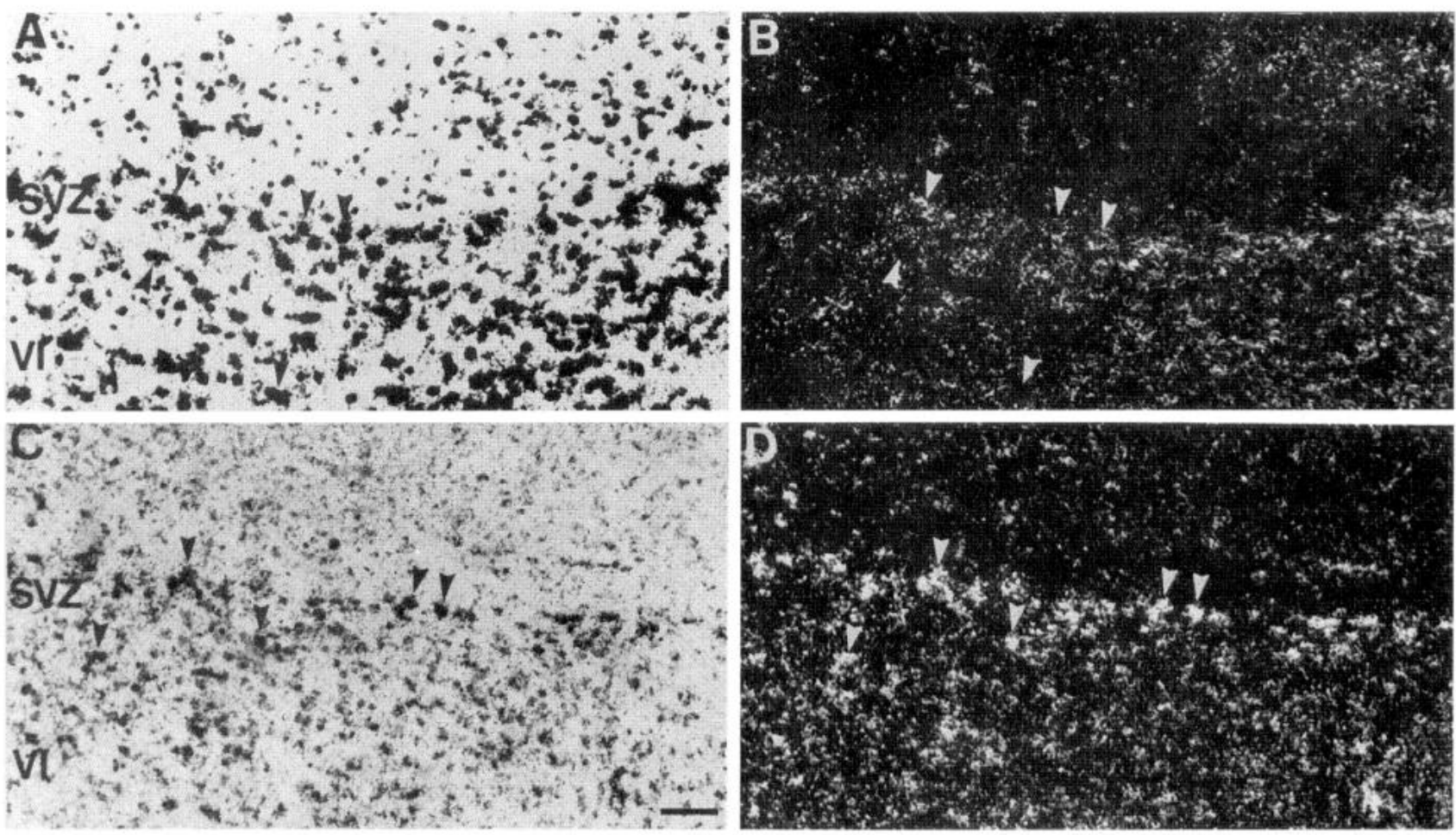

Figure 8. Selective postnatal increase of mEAAT2 mRNA expression in the subventricular zone. Distribution of mEAAT2 mRNA in the subventricular zone of P14 $(A, B)$ and adult $(C, D)$ C67BL/6 mouse brain. Bright-field $(A)$ and dark-field $(B)$ views of mEAAT2 mRNA in the P14 subventricular zone $(S V Z)$ and cortical layer $V I$. Bright-field $(C)$ and dark- field $(D)$ views of mEAAT2 mRNA distribution in the adult subventricular zone $(S V Z)$ and cortical layer VI. No corresponding increase was seen for the mEAAT1 transcript. Arrowheads indicate signal distribution over cell somas. Scale bar (shown in C): $25 \mu \mathrm{m}$.

cellular localization of the mEAAT2 transcript in the Purkinje cell layer predominated in the processes and cell somas of the Bergmann glia (Fig. 11). In the adult cerebellar cortex, low levels of mEAAT1 and mEAAT2 mRNA expression were detected over cell processes in the granular layer and in the molecular layer immediately adjacent to the Purkinje cell layer (Fig. 11, Table 2).

\section{Commissural white matter tracts}

Adult forebrain commissural projections are established during late embryonic and early postnatal development in the rodent (Ivy and Killackey, 1982) and result from extensive pruning and elimination of axon collaterals. Axon-glia interactions are believed to play a key role in the refinement of homotopic contralateral projections through carrier-mediated release of glutamate and activation of ionotropic and metabotropic excitatory amino acid receptors on glial membranes. At P0, mRNAs for EAATs were present at relatively low abundance in the fimbria and corpus callosum (Fig. 6). At the cellular level, signal distribution for the mEAAT1 probe was found predominantly over glial cell somas, whereas the signal distribution of the mEAAT2 probe in the $\mathrm{P} 0$ brain was more diffuse, suggesting that mEAAT2 mRNA was localized in glial processes rather than in cell bodies (Fig. 12). Increases in mEAAT1 and mEAAT2 mRNA expression at P14 in the corpus callosum and fimbria (Table 2) correlate with continuing oligodendrocyte proliferation and myelination. In the adult brain, the signal distribution of the mEAAT2 probe became less diffuse and more concentrated over cell somas in the fiber tracts (Fig. 12).

\section{DISCUSSION}

We have characterized the CNS embryonic and postnatal localizations of EAA transporter mRNAs in situ with subtype-specific antisense oligonucleotides designed to the mouse EAAT1 and EAAT2 C-terminal coding sequences (Tanaka, 1993b; Sutherland et al., 1995). During late embryogenesis and throughout postnatal CNS development, we observe distinct but overlapping patterns of EAAT subtype-specific mRNA expression. At E15, E17, E19, and P0, mEAAT1 and mEAAT2 transcript localizations correlate with the onset and principle sites of gliogenesis in the developing brain. During postnatal CNS development, mEAAT1 mRNA expression disappears in the subventricular zone coincident with a dramatic decrease in mitotic activity, whereas unexpectedly strong mEAAT2 mRNA expression persists in the subependymal proliferative region (Privat and Leblond, 1972; Morshead and van der Kooy, 1992), even in the adult murine brain. At the subcellular level, a shift in the predominance of the mEAAT2 transcript from proximal cell processes to a preferential localization within cell somas in cortical layers V and VI, the subventricular zone, and commissural fiber tracts occurs during the later stages of postnatal CNS development. These distinctive developmental expression patterns suggest multiple functional roles for glutamate transporters in the CNS.

\section{Role of EAAT mRNA expression in proliferative zones of the CNS}

During gliogenesis, glioblasts congregate in the subventricular (subependymal) zone around the lateral ventricles of the E14 mouse forebrain (Sturrock and Smart, 1980; Sturrock, 1982), where both type 1 astrocytes and O-2A progenitor cells are hypothesized to originate by transformation from radial glial cells (Jacobson, 1991). At E15, E17, and E19, we detect strong expression of the EAAT mRNAs in the ventricular zones of the cerebellum (mEAAT1) and forebrain (mEAAT1, mEAAT2). The abundance of mEAAT1 expression subsequently decreases with 

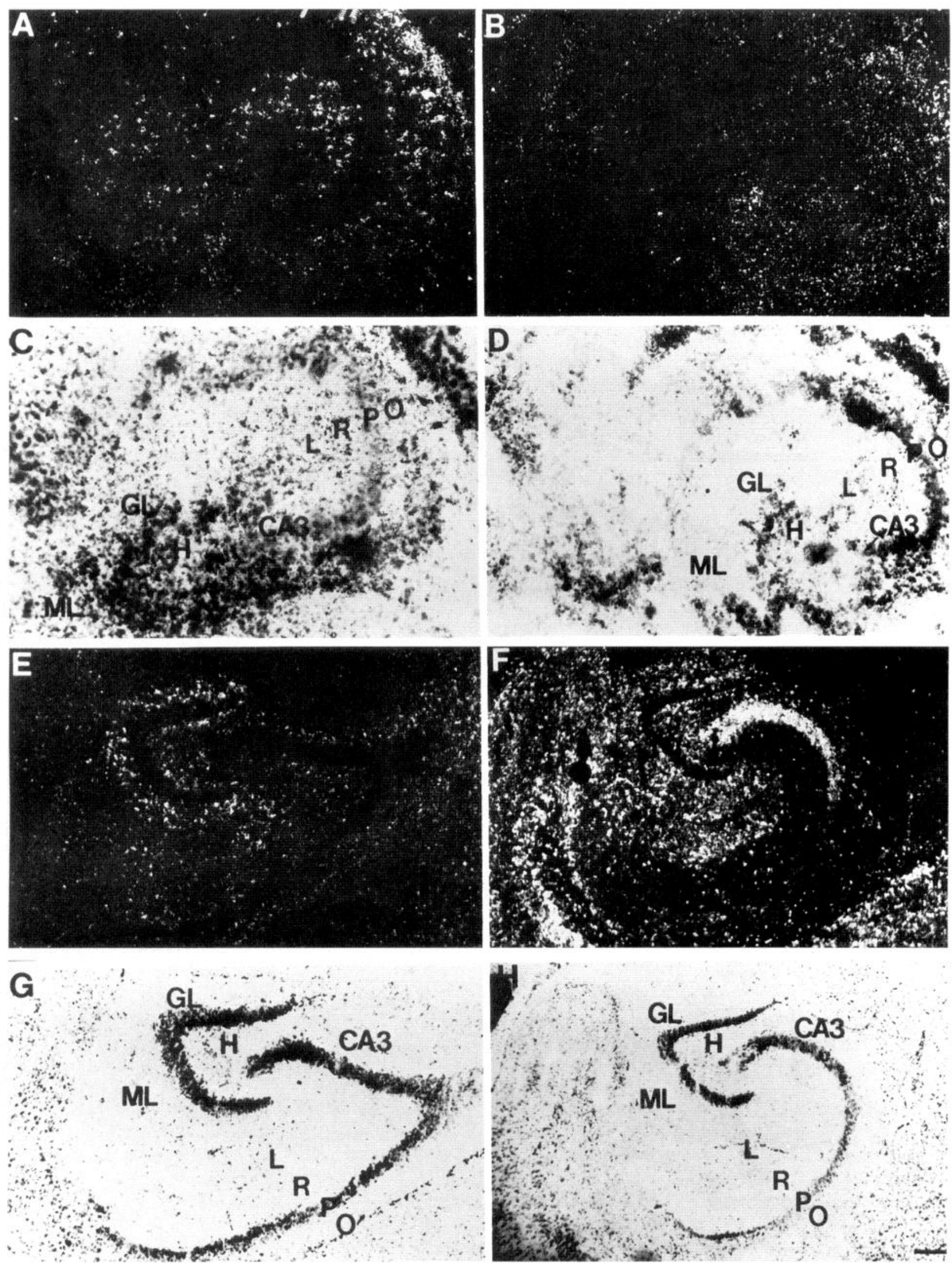

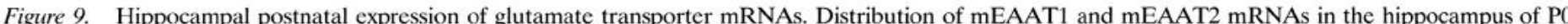

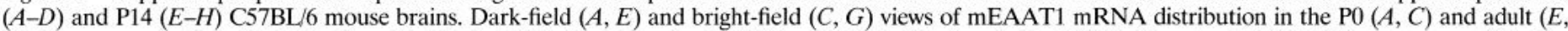

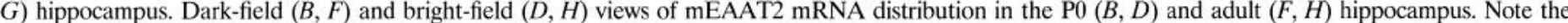

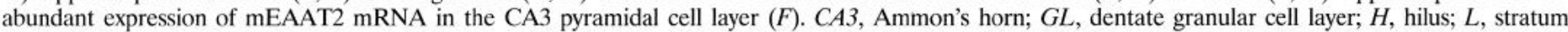
lacunosum moleculare; $M L$, dentate molecular layer; $O$, stratum oriens; $P$, stratum pyramidale; $R$, stratum radiatum. Scale bar (shown in $H$ ): $27 \mu \mathrm{m}$. 

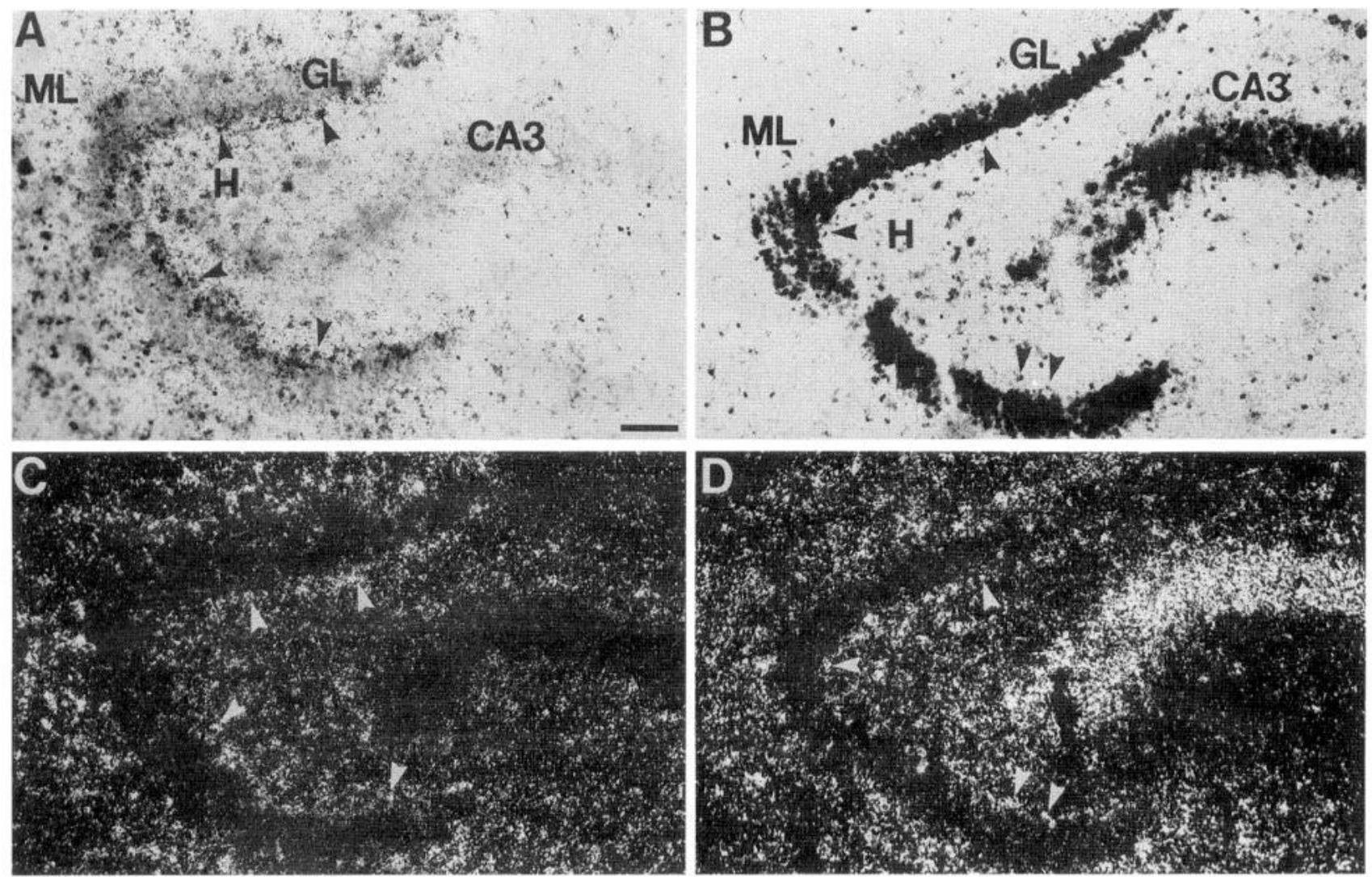

Figure 10. Intrahilar localization of mEAAT1 and mEAAT2 in adult hippocampus. Bright-field $(A, B)$ and dark-field $(C, D)$ views of mEAAT1 $(A, C)$ mRNA and mEAAT2 $(B, D)$ mRNA distribution. Arrows indicate labeling in a single layer of hilar interneurons bordering the inner dentate granule cell layer. $C A 3$, Ammon's horn pyramidal cell layer; $G L$, granular cell layer of dentate gyrus; $H$, hilus; $M L$, molecular layer of dentate gyrus. Scale bar (shown in $A$ ): $26 \mu \mathrm{m}$.

the completion of cell migration and a concomitant decrease in mitotic activity within the subventricular zone, suggesting that mEAAT1 transcript expression occurs preferentially in progenitor cells and radial glia.

NMDA-dependent cell migration has been demonstrated in cultured cerebellar granule cells and is affected by the blockade of EAAT uptake by $p$-chloromercuriphenylsulfonic acid (Komuro and Rakic, 1993). Nonvesicular release of glutamate from astrocytes has recently been suggested as a mechanism for NMDA receptor-mediated neuronal calcium increases (Parpura et al., 1994) associated with neuronal and glial cell migration. During later stages of embryogenesis, the expression of mEAAT1 and mEAAT2 mRNAs coincides with that of the NMDA receptor subunit mRNAs, NR1 and NR2B (Monyer et al., 1994), in the embryonic cortex and cerebellum. Spontaneous NMDA currents initiated by endogenous glutamate have been demonstrated in fetal neurons by patch-clamp recording from rat neocortical slices (LoTurco et al., 1991). This type of agonist activity is associated with nonvesicular release via a carrier-mediated process, and under certain ionic conditions, transporter proteins may act as the carrier through reverse-uptake and release of intracellular glutamate. Hence the expression of EAAT mRNA in radial glia processes could provide an important mechanism for regulating NMDA-dependent neuronal cell migration through the reverse uptake of glutamate.

Several lines of evidence support the idea that glutamate transport could contribute to the regulation of cell proliferation. The temporal and spatial expression profiles of EAAT mRNAs in the ventricular zones during embryogenesis coin- cide with those of several CNS-specific morphogenic factors, including brain lipid-binding protein (BLBP), brain-enriched hyaluronan-binding protein (BEHAB), and brain factor 1 (BF1), which are involved in neuronal and glial differentiation and proliferation (Feng et al., 1994; Kurtz et al., 1994; Jaworski et al., 1995; Xuan et al., 1995). Like mEAAT1, the expression of BLBP, BEHAB, and BF-1 mRNAs is greatest during the period of rapid cell division and declines as the cells become postmitotic. In primary cell culture, anti-BLBP antibodies specifically block glial and neuronal differentiation without affecting cell proliferation (Feng et al., 1994), and mice with a null mutation in the BF-1 gene show a severe reduction in the size of the cerebral hemispheres attributable to disruption of both cell proliferation and differentiation. Although null mutants in the EAAT genes have not yet been constructed, the temporal and spatial colocalization of EAAT mRNAs with putative morphogenic factor mRNAs in progenitor, undifferentiated, and radial glia cells suggests that glutamate transport may be part of a signaling pathway important for early steps in neuroepithelial development.

A second line of evidence further points to a possible mechanism linking EAA transport with proliferation rate. Mitotic activity in the ventricular zone of developing neocortex is influenced by depolarization of mitotic cell membranes through the activation of kainate-gated ion channels (LoTurco et al., 1991). Membrane depolarization results in decreased mitotic activity, presumably attributable to increased calcium entry and the subsequent modulation of $\mathrm{Ca}^{2+}$-sensitive cell cycle events. These cells are electrically coupled through gap 

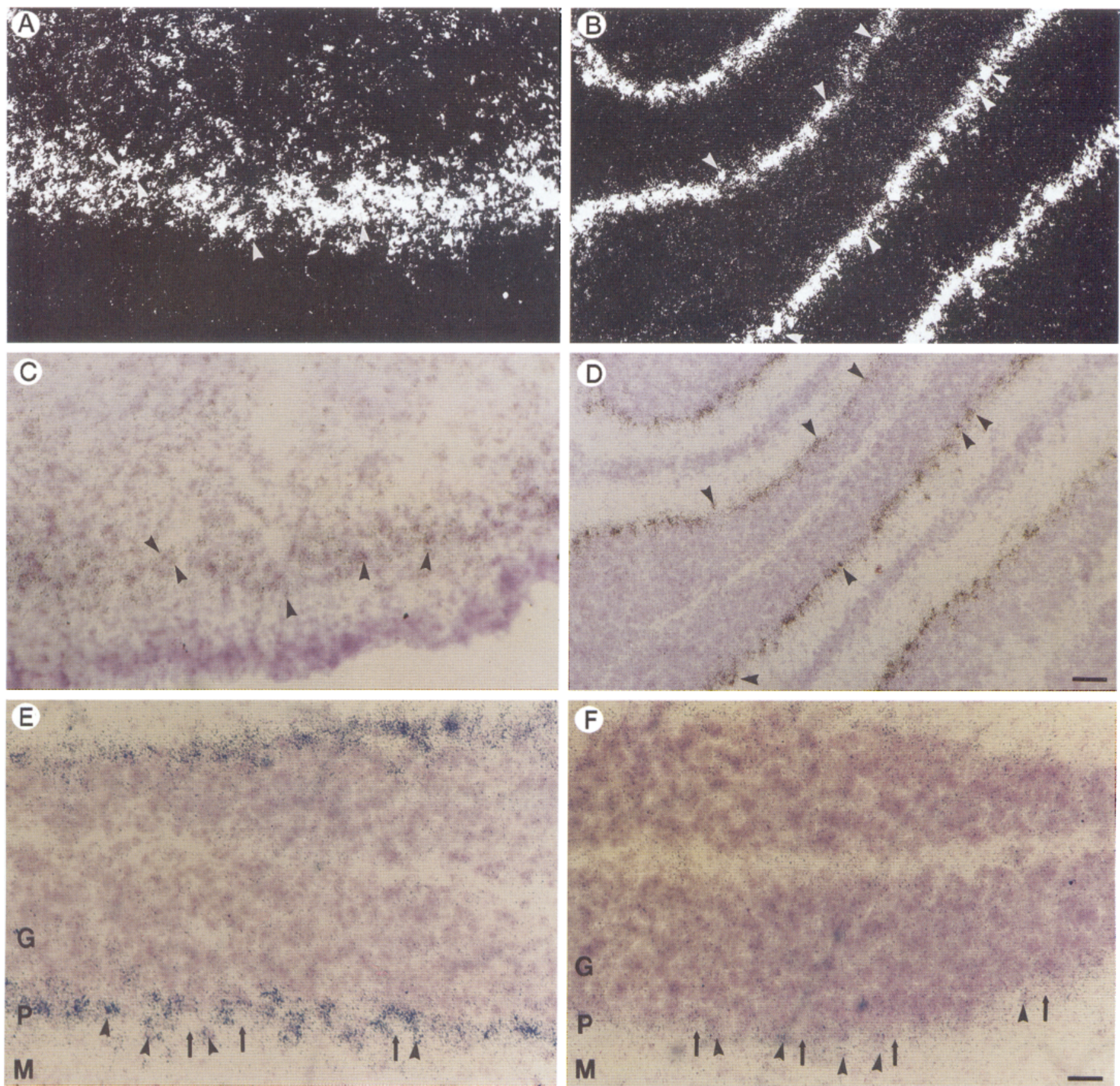

Figure 11. Postnatal development of glutamate transporter expression in cerebellar cortex. Dark-field $(A)$ and bright-field $(C)$ views of mEAAT1 in P0 cerebellar cortex. Arrowheads indicate dense labeling over migrating cells. Adult expression pattern $(B, D)$ shows scant labeling of mature granular cells, bordered by strong expression of mEAAT1 in Purkinje cell layer. $E$, Higher magnification of adult cerebellar cortex reveals intense mEAAT1 labeling of Bergmann glial cells (arrowheads) and lighter labeling of Purkinje cells (arrows). F, mEAAT2 mRNA is expressed less abundantly in the Purkinje cell layer. $G$, Granular cell layer; $P$, Purkinje cell layer; $M$, molecular layer. Scale bars: $D, 6 \mu \mathrm{m} ; F, 10 \mu \mathrm{m}$.

junctions (LoTurco and Kriegstein, 1991), and thus glutamate release by reverse uptake through EAATs may play a role in the timing and synchronized termination of mitotic activity by regulating glutamate levels in the proliferative zones of the developing brain.

Although both EAAT mRNAs are abundantly expressed at birth in the telencephalic ventricular zone, only mEAAT2 transcript expression persists throughout the later stages of $\mathrm{CNS}$ postnatal development and in the subependymal zone of the adult brain. One possible role for persistent expression may be related to neuronal survival. Cohen-Cory et al. (1991) demonstrated that NGF specifically enhances Purkinje cell survival in culture, and that NGF together with glutamate or aspartate promoted a twofold increase in survival, as well as increased Purkinje cell size and neurite claboration. The effects required simultaneous exposure to depolarization and trophic factor and were ineffective with either 

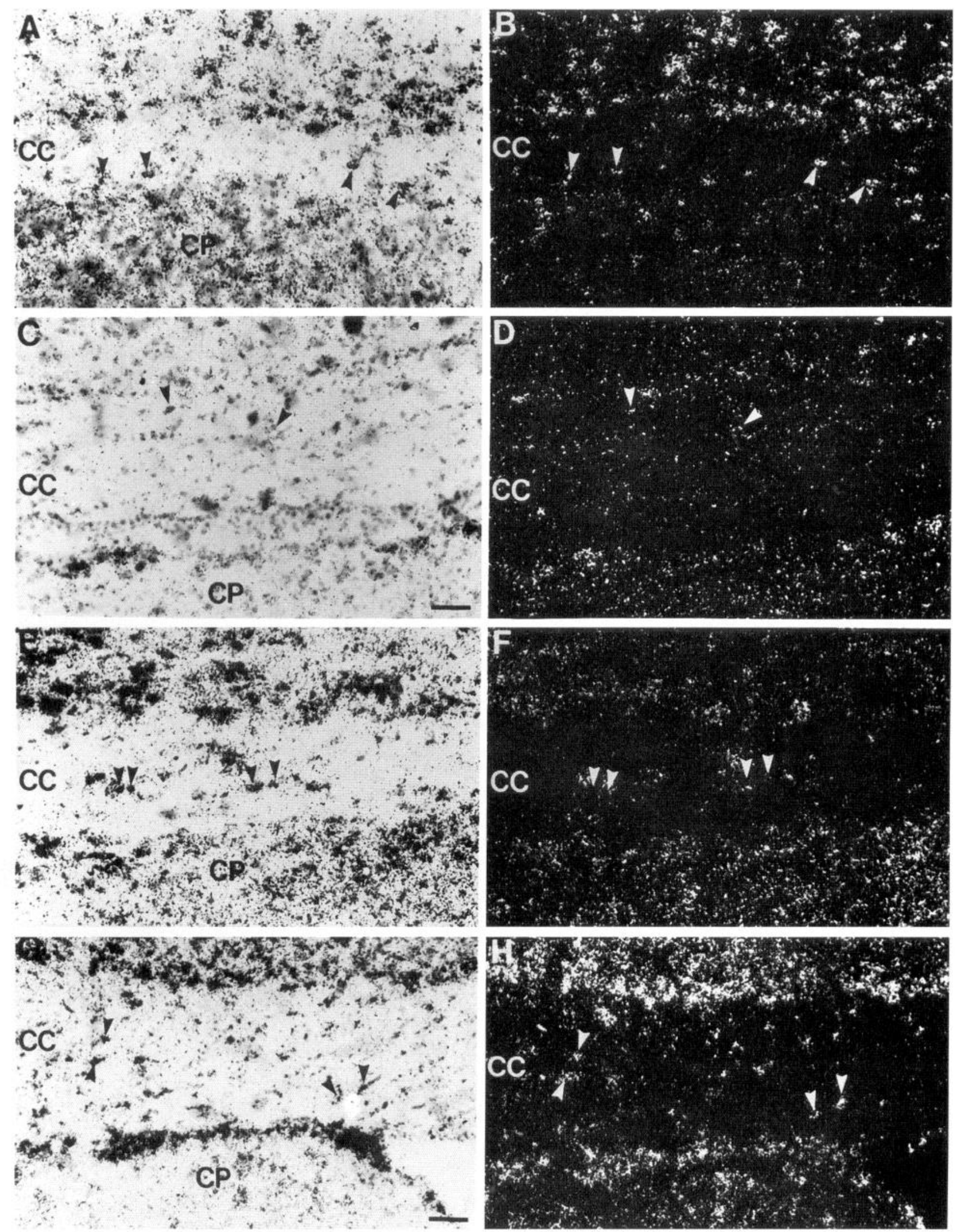

Figure 12. Distribution of mEAAT1 and mEAAT2 transcripts in the commissural tracts of P0, P14, and adult C57BL/6 mouse brains. Bright-field (A) and dark-field $(B)$ views of mEAAT1 mRNA distribution in the P0 corpus callosum; arrowheads indicate labeling of cells within the fiber tract. Bright-field $(C, E, G)$ and dark-field $(D, F, H)$ views of mEAAT2 mRNA distribution in the P0 $(C, D), \mathrm{P} 14(E, F)$, and adult $(G, H)$ corpus callosum. Note progressive increase in mEAAT2 labeling of white matter cell bodies with age $(D, F, H)$. Arrowheads indicate labeling of cells within the fiber tract. $C C$, Corpus callosum; $C P$, caudate putamen. Scale bars: $C, 26 \mu \mathrm{m} ; G, 28 \mu \mathrm{m}$. 
alone. These data suggest an important role for extracellular glutamate concentration in cell survival in the mature nervous system, particularly in those cells with elaborate neurite formation.

\section{Glutamate transport and axon-glia signaling}

Although there are no known vesicular mechanisms for amino acid release in white matter, mammalian and frog nerves have been shown to release glutamate and adenosine during electrical stimulation. Glial cells along axons can also generate intracellular calcium signals in response to direct application of ligands like glutamate and ATP (Kriegler and Chiu, 1993). Glutamate transporters are present in axons of the squid, crab, and rat (Baker and Potashner, 1971, 1973; Rothstein et al., 1994), and after prolonged activity in neonatal axons, may play a role in the nonvesicular release of glutamate through reverse uptake.

During later stages of embryogenesis, both EAAT mRNAs are present in the olfactory tract, and during early postnatal CNS development (PO-P7), mEAAT1 and mEAAT2 transcripts are expressed in the commissural fiber tracts of the corpus callosum and fimbria. From P0 through P14, silver grain distribution for the mEAAT2 probe was diffuse, indicative of localization of the InRNA either over cell processes or along unmyelinated axons. In the adult corpus callosum, however, distribution of the signal for mEAAT2 mRNA was found predominantly over cell bodies and therefore may also represent transcript expression in astrocytes or oligodendrocytes. Immunocytochemical staining with subtypespecific antibodies to EAAT1 and EAAT2 proteins has revealed that some astrocytes in the corpus callosum are capable of expressing both subtypes of EAAT, whereas oligodendrocytes were essentially unlabeled (Lehre et al., 1995). High-affinity, $\mathrm{Na}^{+}$coupled glutamate transport has been demonstrated in both Type 1 astrocytes cultured from rat cerebellum (Wyllie et al., 1991) and in oligodendrocytes cultured from rat brain (Oka et al., 1993).

If glutamate is the signal that couples axon impulse activity to glial calcium influx, then frequency-dependent release of glutamate from axons might be translated into glial $\mathrm{Ca}^{2+}$ responses via metabotropic glutamate receptors, which have been found on O-2A progenitor cells (Barres et al., 1990; Berger et al., 1992) and Bergmann glial cells (Burnashev et al., 1992; Muller et al., 1992). Glial signaling along axons may be regulated developmentally, since glial calcium transients occur during spontaneous firing in growing axons and cease after myelination. Immunocytochemical analysis of early postnatal fiber tracts with subtype-specific EAAT antibodies should aid in determining the exact localization of these EAAT proteins.

\section{Neuronal localization of mEAAT1 and mEAAT2 mRNAs}

Although several immunocytochemical studies with subtypespecific anti-peptide EAAT antibodies have defined EAAT1 and EAAT2 as glial-specific transporters, we observed the localization of the corresponding EAAT mRNAs in both neuronal and glial cell populations. Neuronal localizations of the mEAAT1 mRNA clearly were present during embryogenesis in cortical plate neurons and in a band of intrahilar interneurons bordering the inner layer of the dentate gyrus granular cell population. Expression of mFAAT1 mRNA in some Purkinje cells in postnatal and adult cerebella is more difficult to interpret because of the high level of mEAAT1 mRNA in Bergmann processes that envelop the Purkinje cell bodies. Interestingly, we observed strong expression of mEAAT2 mRNA in the hippocampal pyramidal cell layer, particularly in the $\mathrm{CA} 3$ region throughout postnatal development. This discrepancy between mEAAT2 mRNA expression and the lack of mEAAT2 protein in this subset of neurons may be attributable to abnormal processing of the idiotype recognized by the antibodies, to the presence of an intracellular pool of untranslated mRNA, or as suggested by Torp et al. (1994), to a disparity between the amount of EAAT 2 mRNA expressed and the amount of EAAT2 protein translated, resulting in levels of EAAT2 protein below the detectable range for their antibody.

\section{Localization of mEAAT 1 and mEAAT2 mRNAs in cell processes}

Although most neuronal mRNAs seem to be confined to the perikarya of nerve cells, a small number of mRNAs coding for dendritic proteins such as Arc, BC1, MAP2, the $\alpha$ subunit of CamKII, and several glutamate receptor subunits (Lyford et al., 1995; Tiedge et al., 1991, 1993; Chicurel et al., 1993; Garner et al., 1988; Burgin et al., 1990; Miyashiro et al., 1994) have been detected recently in the somatodendritic compartments of neurons in the rat CNS. The subcellular localization of mRNAs in dendrites coincides with the accumulation of polyribosomes during the peak period of synaptogenesis (Steward and Falk, 1986), and hence the protein translated from these ribosomes may be involved in the formation, differentiation, and modification of synapses (Steward and Levy, 1982; Steward and Falk, 1986). Differential intracellular sorting and targeting of specific mRNAs has also been demonstrated in several glial cell types, including oligodendrocytes and astrocytes (Trimmer et al., 1991; Rao and Steward, 1993). We found that mEAAT1 and mEAAT2 mRNAs were localized in both glial cell somas and processes of the cerebellar cortex, commissural fiber tracts, cerebral cortex, and hippocampus during CNS development. Because one of the principle functions of EAATs is the maintenance of glutamate levels below neurotoxic concentrations, the localization of EAAT transcripts at sites of local protein synthesis may allow for rapid changes in uptake activity. During later stages of postnatal CNS development, changes also occurred in the subcellular localization of the mEAAT2 transcript in cells within cortical layers V and VI, the subventricular zone, and commissural fiber tracts, where the transcript localization shifted from a predominance in proximal cellular processes to a preferential distribution within cell somas. Such changes in subcellular localization of glutamate transporter mRNAs during CNS development may reflect a regulatory role for glutamate transport before and during synaptogenesis.

\section{REFERENCES}

Altman J, Das GD (1966) Autoradiographic and histological studies of postnatal neurogenesis. I. A longitudinal investigation of the kinetics, migration and transformation of cells incorporating tritiated thymidine in neonate rats, with special reference to postnatal neurogenesis in some brain regions. J Comp Neurol 126:337-390.

Amara SG, Arriza JL (1993) Neurotransmitter transporters: three distinct gene families. Curr Opin Neurobiol 3:337-344.

Arenander AT, de Vellis J, Herschman HR (1989) Introduction of c-fos and TIS genes in cultured rat astrocytes by neurotransmitters. J Neurosci Res 24:107-114.

Arriza JL, Fairman WA, Wadiche JI, Murdoch GH, Kavanaugh MP, Amara SG (1994) Functional comparisons of three glutamate transporter subtypes cloned from human motor cortex. J Neurosci 14:5559-5569.

Attwell D, Mobbs P (1994) Neurotransmitter transporters. Curr Opin Neurobiol 4:353-359.

Attwell D, Szatkowski M, Barbour B (1993) Non-vesicular release of neurotransmitter. Neuron 11:401-407.

Baker PF, Potashner SJ (1971) The dependence of glutamate uptake by crab nerve on external $\mathrm{Na}^{+}$and $\mathrm{K}^{+}$. Biochim Biophys Acta 249:616-622. 
Baker PF, Potashner SJ (1973) Glutamate transport in invertebrate nerve: the relative importance of ions and metabolic energy. J Physiol (Lond) 232:26P-27P.

Barres BA, Koroshetz WJ, Swartz KJ, Chun LLY, Corey DP (1990) Ion channel expression by white matter glia: the $\mathrm{O}-2 \mathrm{~A}$ glial progenitor cell. Neuron 4:507-524.

Bayer SA (1980) Development of the hippocampal region in the rat. I. Neurogenesis examined with ${ }^{3} \mathrm{H}$-thymidine autoradiography. J Comp Neurol 190:87-114.

Berger T, Walz W, Schnitzer J, Kettenmann H (1992) GABA and glutamatc-activated currents in glial cells of the mouse corpus callosum slice. J Neurosci Res 31:21-27.

Bouvier M, Szatkowski M, Amato A, Attwell D (1992) The glial cell glutamate uptake carrier countertransports $\mathrm{pH}$-changing anions. Nature 360:471-474.

Burgin KE, Waxham MN, Rickling S, Westgate SA, Mobley WC, Kelly PT (1990) In situ hybridization histochemistry of $\mathrm{Ca} /$ calmodulin dependent protein kinase in developing rat brain. J Neurosci 10:1788-1789.

Burnashev N, Khodorova A, Jonas P, Helm PJ, Wisden W, Monyer H, Seeburg PH, Sakmann B (1992) Calcium-permeable AMPA-kainate receptors in fusiform cerebellar glial cells. Science 256:1566-1570.

Chicurel ME, Terrian DM, Potter H (1993) mRNA at the synapse: analysis of synaptosomal preparation enriched in hippocampal dendritic spines. J Neurosci 13:4054-4063.

Choi DW, Maulucci-Geede M, Kriegstein AR (1987) Glutamate neurotoxicity in cortical cell culture. J Ncurosci 7:357-368.

Chomczynski P, Sacchi N (1987) Single step method of RNA isolation by acid guanidinium thiocyanate phenol-chloroform extraction. Anal Biochem 162:156-159.

Cohen-Cory S, Drcyfus CF, Black IB (1991) NGF and excitatory ncurotransmitters regulate survival and morphogenesis of cultured cerebellar Purkinje cells. J Neurosci 11:462-471.

Fairman WA, Vandenberg RJ, Arriza JL, Kavanaugh MP, Amara SG (1995) An excitatory amino-acid transporter with properties of a ligand-gated chloride channel. Nature 375:599-603.

Feng L, Hatten ME, Heintz N (1994) Brain lipid-binding protcin (BLBP): a novel signaling system in the developing mammalian CNS. Neuron 12:895-908.

Garner C, Tucker R, Matus A (1988) Selective localization of messenger RNA for cytoskeletal protein MAP2 in dendrites. Nature 336:674-677.

Ikeda M, Nakazawa T, Abe K, Kaneko T, Yamatsu K (1989) Extracellular accumulation of glutamate in the hippocampus induced by ischcmia is not calcium-dependent: in vitro and in vivo evidence. Neurosci Lett 96:202-206.

Ivy GO, Killackey HP (1982) Ontogenetic changes in the projections of neocortical neurons. J Neurosci 2:735-743.

Jacobson M (1991) Developmental neurobiology, 3rd Ed. New York: Plenum.

Jaworski DM, Kelly GM, Hockfield S (1995) The CNS-specific hyaluronan-binding protein $\mathrm{BEHAB}$ is expressed in ventricular zones coincident with gliogenesis. J Neurosci 15:1352-1362.

Kanai Y, Hediger MA (1992) Primary structure and functional characterization of a high-affinity glutamate transporter. Nature 360:467-471.

Kanai Y, Smith CP, Hediger MA (1993) The elusive transporters with a high affinity for glutamate. Trends Neurosci 16:365-370.

Kanner BI (1993) Glutamate transporters from brain: a novel neurotransmitter transporter family. FEBS Lett 325:95-99.

Kawakami H, Kohichi T, Nakayama T, Inouc K, Nakamura S (1994) Cloning and expression of a humant glutanate transporter. Biochem Biophys Res Commun 199:171-176.

Kirschner MA, Copeland NG, Gilbert DJ, Jenkins NA, Amara SG (1994) Mousc excitatory amino acid transporter EAAT2: isolation, characterization, and proximity to neuroexcitability loci on mouse chromosome 2. Gcnomics 24:218-224.

Komuro H, Rakic P (1993) Modulation of neuronal migration by NMDA receptors. Science 260:95-97.

Kriegler S, Chiu SY (1993) Calcium signaling of glial cells along mam malian axons. J Neurosci 13: 4229-4245.

Kurtz A, Zimmer A, Schnütgen F, Brüning $G$, Spener F, Müller T (1994) The expression pattern of a novel gene encoding brain-fatty acid binding protein correlates with neuronal and glial cell development. Development 120:2637-2649.

Kytc J, Doolittle RF (1982) A method for displaying the hydropathic character of a protein. J Mol Biol 157:105-132.
Lehre KP, Levy LM, Ottersen OP, Storm-Mathisen J, Danbolt NC (1995) Differential expression of two glial glutamate transporters in the rat brain: quantitative and immunocytochemical observations. J Neurosci 15:1835-1853.

LoTurco JJ, Kriegstein AR (1991) Clusters of coupled neuroblasts in embryonic neocortex. Science 252:563-566.

LoTurco JJ, Blanton MG, Kriegstein AR (1991) Initial expression and endogenous activation of NMDA channels in early neocortical development. J Neurosci 11:792-799.

Lyford GL, Yamagata K, Kaufmann WE, Barnes CA, Sanders LK, Copeland NG, Gilbert DJ, Jenkins NA, Lanahan AA, Worley PF (1995) Arc, a growth factor and activity-regulated gene, encodes a novel cytoskeleton-associated protein that is enriched in neuronal dendrites. Neuron 14:433-445.

Madl JE, Burgesser K (1993) Adenosine triphosphate depletion reverses sodium-dependent neuronal uptake of glutamate in rat hippocampal slices. J Neurosci 13:4429-4444.

Mattson MP, Lee RE, Adams ME, Guthrie PB, Kater SB (1988) Interactions between entorhinal axons and target hippocampal neurons: a role of glutamate in the development of hippocampal circuitry. Neuron $1: 865-876$.

McDonald JW, Johnston MV (1990) Physiological and pathophysiological roles and excitatory amino acids during central nervous system development. Brain Res Dev 15:41-70.

Mennerick S, Zorumski CF (1994) Glial contributions to excitatory neurotransmission in cultured hippocampal cells. Nature 368:59-62.

Miller MW (1988) Development of projection and local circuit neurons in ncocortex. In: Development and maturation of cercbral cortex, Vol 7 (Peters A, Jones EG, eds), pp 133-175. New York: Plenum.

Miyashiro K, Dichter M, Eberwine J (1994) On the nature and differential distribution of mRNAs in hippocampal neurites: implications for ncuronal functioning. Proc Natl Acad Sci USA 91:10800-10804.

Monyer H, Burnashev N, Lauric DJ, Sakmann B, Secburg PH (1994) Developmental and regional expression in the rat brain and functional properties of four NMDA receptors. Neuron 12:529-540.

Morshead CM, van der Kooy D (1992) Postmitotic death is the fate of constitutively proliferating cells in the subependymal layer of the adult mouse brain. J Neurosci 12:249-256.

Muller T, Moller T, Berger T, Schnitzer J, Kettenmann H (1992) Calcium entry through kainate receptors and resulting potassium-channel blockade in Bcrgmann glial cells. Science 256:1563-1566.

Nicholls D, Attwell D (1990) The relcase and uptake of excitatory amino acids. Trends Pharmacol Sci 11:462-468.

Nicoletti F, Magri C, Ingrao F, Bruno V, Catania MV, Dell'Albani $P$, Condorelli DF, Avola R (1990) Excitatory amino acids stimulate inositol phospholipid hydrolysis and reduce proliferation in cultured astrocytes. I Neurochem 54:771-777.

Oka A, Belliveau MJ, Rosenberg PA, Volpe JJ (1993) Vulnerability of oligodendroglia to glutamate: pharmacology, mechanisms, and prevention. J Ncurosci 13:1441-1453.

Parpura V, Basarsky TA, Liu F, Jeftinija K, Jeftinija S, Haydon PG (1994) Glutamate-mediated astrocyte-ncuron signalling. Nature 369:744-747.

Pearce IA, Cambray-Deakin MA, Burgoync RD (1987) Glutamate acting on NMDA receptors stimulates neurite outgrowth from cerebellar granule cells. FEBS Lett 223:143-147.

Pines G, Danbolt NC, Bjørås M, Zhang Y, Bendahan A, Eide L, Koepsell H, Storm-Mathisen J, Secberg E, Kanner BI (1992) Cloning and expression of a rat brain 1. glutamate transporter. Nature 360:464-467.

Privat A, Leblond CP (1972) The subependymal layer and neighboring region in the brain of the young rat. J Comp Neurol 146:277-302.

Rakic P (1971) Guidance of neurons migrating to the fetal monkcy neocortex. Brain Res 33:471-476.

Rakic P (1972) Mode of cell migration to the superficial layers of fetal monkey neocortcx. J Comp Neurol 145:61-84.

Rao A, Steward O (1993) Evaluation of RNAs present in synaptodendrosomes: dendritic, glial and neuronal cell body contribution. J Neurochem 61:835-844.

Rothstein JD, Martin L, Levcy AI, Dykes-Hoberg M, Jin L, Wu D, Nash N, Kuncl RW (1994) Localization of neuronal and glial glutamate transporters. Neuron 13:713-725.

Shashidharan P, Plaitakis A (1993) Cloning and characterization of a glutamate transporter cDNA from human cerebcllum. Biochim Biophys Acta 1216:161-164. 
Shashidharan P, Wittenberg I, Plaitakis A (1994) Molecular cloning of human brain glutamate/aspartate transporter II. Biochim Biophys Acta 1191:393-396.

Steward O, Falk PM (1986) Protein-synthetic machinery at postsynaptic sites during synaptogenesis: a quantitative study of the association between polyribosomes and developing synapses. J Neurosci 6: 412-423.

Steward O, Levy WB (1982) Preferential lucalization of polyribosomes under the base of dendritic spines in granule cells of the dentate gyrus. J Neurosci 2:284-291.

Storck T, Schulte S, Hofmann K, Stoffel W (1992) Structure, expression and functional analysis of a $\mathrm{Na}^{+}$-dependent glutamatc/aspartate transporter from rat brain. Proc Natl Acad Sci USA 89:10955-10959.

Sturrock RR (1982) Cell division in the normal central nervous system. Adv Cell Neurobiol 3:3-33.

Sturrock RR, Smart IHM (1980) A morphological study of the mouse subependymal layer from embryonic life to old age. J Anat 130:391-415.

Sutherland ML, Delaney TA, Noebels JL (1995) Molecular characterization of a high affinity mouse glutamate transporter. Gene 162:271-274.

Swarna M, Rao DN, Reddy PP (1989) Dicarboxylic aminoaciduria associated with mental retardation. Hum Genet 82:299-300.

Szatkowski M, Barbour B, Attwell D (1990) Non-vesicular release of glutamate from glial cells by reversed electrogenic glutamate uptake. Nature 348:443-446.

Takahashi M, Kovalchuk Y, Attwell D (1995) Pre- and postsynaptic determinants of EPSC waveform at cerebellar climbing fiber and parallel fiber to Purkinje cell synapses. J Neurosci 15:5693-57(12.
Tanaka K (1993a) Expression cloning of a rat glutamate transporter. Neurosci Res 16:149-153.

Tanaka K (1993b) Cloning and expression of a glutamate transporter from mouse brain. Neurosci Lett 159:183-186.

Tiedge H, Fremeau Jr RT, Weinstock PH, Arancio O, Brosius J (1991) Dendritic location of neural BC1 RNA. Proc Natl Acad Sci USA 88:2093-2097.

Tiedge H, Zhou A, Thorn NA, Brosius J (1993) Transport of BC1 RNA in hypothalamo-neurohypophyseal axons. J Neurosci 13:4214-4219.

Torp R, Danbolt NC, Babaie E, Bjørås M, Seeberg E, Storm-Mathisen J, Ottersen OP (1994) Differential expression of two glial glutamate transporters in the rat brain: an in situ hybridization study. Eur J Neurosci 6:936-942.

Trimmer PA, Phillips LL, Steward O (1991) Combination of in situ hybridization and immunocytochemistry to detect messenger RNAs in identified CNS neurons and glia in tissue culture. J Histochem Cytochem 39:891-898.

Wadiche JI, Amara SG, Kavanaugh MP (1995a) Ion fluxes associated with excitatory amino acid transport. Neuron 15:721-728.

Wadiche JI, Arriza JL, Amara SG, Kavanaugh MP (1995b) Kinetics of a human glutamate transporter. Neuron 14:1019-1027.

Wyllie DJA, Mathie A, Symonds CJ, Cull-Candy SG (1991) Activation of glutamate receptors and glutamate uptake in identified macroglia cells in rat cerebellar cultures. J Physiol (Lond) 432:235-258.

Xuan S, Baptista CA, Balas G, Tao W, Soares VC, Lai E (1995) Winged helix transcription factor $\mathrm{BF}-1$ is essential for the development of the cerebral hemispheres. Neuron 14:1141-1146. 